\title{
The Metallogeny of the Tieling Cu-Mo Porphyry Deposit in Eastern Tianshan, NW China: New Insights from Zircon U-Pb, Fluid Inclusion, and H-O-S Stable Isotope Analyses
}

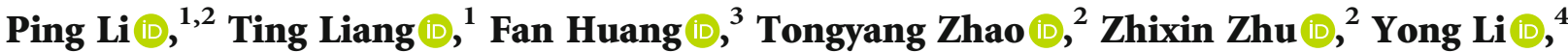 \\ Jing Feng $\left(\mathbb{0},{ }^{5}\right.$ and Lei $\mathrm{He} \mathbb{(}^{1}$ \\ ${ }^{1}$ College of Earth Science and Resources, Chang'an University, Xi'an, Shanxi 710054, China \\ ${ }^{2}$ Geological Survey Academy of Xinjiang, Urumqi, Xinjiang 830000, China \\ ${ }^{3}$ MNR Key Laboratory of Metallogeny and Mineral Assessment, Institute of Mineral Resources, CAGS, Beijing 100037, China \\ ${ }^{4}$ Research Institute of Geology and Mineral Exploration of Xinjiang Nonferrous Geological Exploration Bureau, Urumqi, \\ Xinjiang 830000, China \\ ${ }^{5}$ Xinjiang Bureau of Geological Mineral Exploration and Development, Urumqi, Xinjiang 830000, China
}

Correspondence should be addressed to Ting Liang; liangt@chd.edu.cn and Fan Huang; hfhymn@163.com

Received 26 January 2021; Revised 16 April 2021; Accepted 18 August 2021; Published 21 September 2021

Academic Editor: Paolo Fulignati

Copyright ( 92021 Ping Li et al. This is an open access article distributed under the Creative Commons Attribution License, which permits unrestricted use, distribution, and reproduction in any medium, provided the original work is properly cited.

\begin{abstract}
The eastern Tianshan metallogenic belt is an important molybdenum resource base in Xinjiang and is characterized by large-scale porphyry Mo deposits formed during the Triassic. The Tieling $\mathrm{Cu}-\mathrm{Mo}$ porphyry deposit, which is situated in the western part of the eastern Tianshan metallogenic belt, was recently recognized as being related to Carboniferous granite porphyry. Three stages of hydrothermal mineralization were identified, including quartz + K-feldspar+pyrite \pm molybdenite \pm magnetite (stage I), quartz +molybdenite+pyrite+chalcopyrite (stage II), and quartz+pyrite \pm molybdenite \pm epidote (stage III). Fluid inclusion petrography and microthermometry analyses indicate the presence of gas-liquid inclusions with a $\mathrm{H}_{2} \mathrm{O}-\mathrm{NaCl}$ composition. The ore-forming fluids have a characteristic temperature ranging from 157 to $262^{\circ} \mathrm{C}$ under stage II and 135 to $173^{\circ} \mathrm{C}$ under stage III, which correspond to salinities of 7.2-17.2 wt $\% \mathrm{NaCl}$ equiv. and 5.9 to $9.6 \mathrm{wt} \% \mathrm{NaCl}$ equiv., respectively. The hydrogen and oxygen isotope data indicate that the ore-forming fluids of the Tieling deposit were originally derived from magmatic hydrothermal fluids and then mixed with meteoric water. The sulfur isotope compositions indicate that the ore-forming materials were mainly derived from the Late Carboniferous felsic magma. Furthermore, zircon U-Pb analysis of ore-bearing granite porphyry yields a concordant age of $298.4 \pm 0.7 \mathrm{Ma}$, indicating that the Tieling $\mathrm{Cu}-\mathrm{Mo}$ deposit formed during the Late Carboniferous and differed from that processed under pre-Early Carboniferous and Triassic mineralization in the eastern Tianshan metallogenic belt. These results also indicate that the Tieling porphyry deposit was formed in the transition condition between subduction-related accretion and postcollisional orogeny, and it should be given more attention in prospect evaluations.
\end{abstract}

\section{Introduction}

Porphyry deposits, as one of the most important types of $\mathrm{Cu}-\mathrm{Mo}-\mathrm{Au}$ deposits, have attracted extensive interest from the geologic community $[1,2]$. Subduction-related magmatic arcs are considered to be closely related to porphyry deposits worldwide, especially that of porphyry $\mathrm{Cu}-\mathrm{Mo}$ in the Circum-Pacific metallogenic belt [3-5]. Recent studies of metallogenic systems in China have shown that a postcol- lisional setting is favourable for the development of porphyry deposits [6-10], especially for porphyry Mo-only or Mo-dominated polymetallic deposits in the Dabie orogen [11-13].

The postcollision-type porphyry Mo deposits in eastern Tianshan are found within a Triassic formation [14, 15], and the subduction-type porphyry $\mathrm{Cu}-\mathrm{Mo}$ deposits are characterized by a formation preceding the Early Carboniferous $[16,17]$. However, the Tieling Cu-Mo deposit, which was 
discovered by the Xinjiang Geological Survey Academy during a geochemical element anomaly survey, may be closely related to Late Carboniferous magmatism [18]. As an unexploited blind mineral system, the geological characteristics and metallogenic processes supporting its formation are still unclear. In this contribution, we first report new data, including the zircon $\mathrm{U}-\mathrm{Pb}$ isotopic age of ore-bearing granite porphyry rocks, fluid inclusions, and $\mathrm{H}-\mathrm{O}-\mathrm{S}$ isotopes, to constrain the age of mineralization, determine the origin of the ore-forming fluids and material, and establish a metallogenic model of the Tieling deposit, which will be beneficial to enhance metallogenic theory and provide insights for the exploration of porphyry $\mathrm{Cu}-\mathrm{Mo}$ mineralization in eastern Tianshan.

\section{Geological Background}

The Central Asian Orogenic Belt (CAOB), surrounded by North China, Tarim, European, and Siberian cratons (Figure 1(a)), is a typical accretionary orogenic belt [19, 20], which resulted from collision between the Siberian and Tarim plates (Figure 1(a)) that progressively closed eastwards from the Late Carboniferous to Early Triassic [21, 22]. Eastern Tianshan, located at the southern margin of the CAOB, is an important mineral resource base in China (Figure 1(b)). Many notable deposits have occurred, including the Huangtupo and Xiaorequanzi VMS Cu-(Zn) [23, 24], Tuwu and Yandong porphyry $\mathrm{Cu}$ [16], Baishan and Donggebi porphyry Mo [21, 25], Huangshan and Tulaergen magmatic sulfide $\mathrm{Ni}-\mathrm{Cu}[26,27]$, Kangguer and Shiyingtan orogenic Au [28], and Yamansu volcanic Fe [29] deposits.

Eastern Tianshan, as an important part of the CAOB, has been subdivided into four tectonic units from north to south, namely, the Dananhu-Tousuquan island arc, the Kanggur-Huangshan shear zone, the Aqishan-Yamansu belt, and the Central Tianshan massif, with a series of approximately east-west-trending faults defining the boundaries, including the Dacaotan, Kanggur, Yamansu, and Aqikekuduke faults (Figure 1(c)). The Dananhu-Tousuquan belt comprises Ordovician to Carboniferous volcanic and intrusive rocks that host a series of large porphyry $\mathrm{Cu}-$ (Mo) deposits, such as the Yudai [30], Tuwu, Yandong, Linglong [31], Chihu [32], Fuxing [33, 34], Yuhai [17], and Sanchakou deposits [35]. The Kanggur-Huangshan shear zone, located between the Yamansu and Kanggur faults, contains a set of tectonic slices, disordered strata, and intrusive rocks. Most strata-originating rocks with strong deformation and metamorphism host gold deposits in the west, including the Kangguer, Matoutan, and Shiyingtan deposits [28]. Most mafic-ultramafic rocks in the east host nickelcopper deposits, such as Huangshan, Huangshandong, Huangshannan, Hulu, and Tulargen deposits [26, 27]. Most notably, the Baishan and Donggebi superlarge porphyry Mo deposits formed in the Triassic are also found in the Kanggur-Huangshan shear zone $[25,36]$. The Aqishan-Yamansu belt, located between the Aqikekuduke and Yamansu faults, consists of lavas, volcaniclastic rocks, and terrigenous clastic sedimentary rocks interbedded with bioclastic limestones. Carboniferous granitic intrusions are widely distributed and intrusively bedded by diabase walls [37]. A series of iron deposits related to volcanism have been recognized in this belt, including the Hongyuntan, Bailingshan, Duotoushan, Heijianshan, Chilongfeng, and Yamansu deposits $[18,29$, $38,39]$. The Central Tianshan massif, bounded by the Aqikekuduke fault in the north, is an ancient block composed of calc-alkaline basaltic to andesitic volcanic and volcaniclastic rocks, slightly altered granites and granodiorites, and Precambrian basement rocks [34]. In addition to iron and nickel-copper deposits, there is also a skarn-type tungstenmolybdenum deposit (Xiaobaishitou, Li et al. [40]) in the eastern part of the belt.

\section{Geology of the Tieling Ore District}

The Tieling Cu-Mo deposit is situated southwest of the Bailingshan intrusion in the Aqishan-Yamansu arc belt (Figure 1(c)). The lithostratigraphic unit in the ore district is dominated by the Late Carboniferous Tugutubulake Formation, which consists of tuffaceous dacitic lava with an age of $324 \mathrm{Ma}$ [41]. The intrusive rocks at Tieling mainly include granite porphyry, monzogranite, and granodiorite, with minor gabbroic and dioritic dikes (Figure 2). The monzogranite and granodiorite of the Bailingshan complex were emplaced early into the strata at $317-307 \mathrm{Ma}$ [41], and the gabbroic and dioritic dikes were both emplaced in the Late Carboniferous (311 to $315 \mathrm{Ma}$, Long et al. [37]). The concealed granite porphyry, as an important ore-bearing rock, was emplaced into the granodiorite (Figure 3). The granite porphyry is characterized by a medium- or fine-grained porphyritic texture (Figure 4(a)) and mainly consists of Kfeldspar (65\%) and quartz (30\%), with minor accessory minerals such as molybdenite, zircon, apatite, pyrite, and magnetite. The phenocryst content is approximately $15 \%$ and mainly includes K-feldspar with a particle size of approximately $0.5 \mathrm{~mm}$ (Figure 4(b)). Muscovite is distributed among the $\mathrm{K}$-feldspar and quartz aggregates in sheet form (Figure 4(c)).

The iron orebodies in the NE direction on the surface, which were regarded as target ores, are mainly distributed in the northeastern ore district (Figure 2). Newly identified molybdenum mineralization is only found in the deep part of granite porphyry, forming a combination of "upper iron and lower copper-molybdenum" with the previously mined iron ores. The iron ores are composed of magnetite, haematite, and pyrite [42]. The metal sulfide minerals of $\mathrm{Cu}-\mathrm{Mo}$ mineralization mainly include molybdenite, chalcopyrite, and pyrite, with disseminated, massive, and vein structures, while gangue minerals mainly include K-feldspar, quartz, epidote, and chlorite. Molybdenite occurs as coarse-grained clusters in quartz veins (Figures 4(d) and 4(e)) and as a disseminated mineral (Figure 4(a)) and veinlets in granite porphyry (Figure 4(f)). Molybdenite either exists as independent aggregates (Figures $4(\mathrm{~d}), 4(\mathrm{~g})$, and $4(\mathrm{~h})$ ) or is associated with chalcopyrite and pyrite (Figures $4(\mathrm{e})$ and 4(i)). Wallrock alteration includes silicification, argillization, sericitization, chloritization, epidotization, and biotitization. Silicification and potassic feldspar are closely related to molybdenum mineralization. The alteration of the 


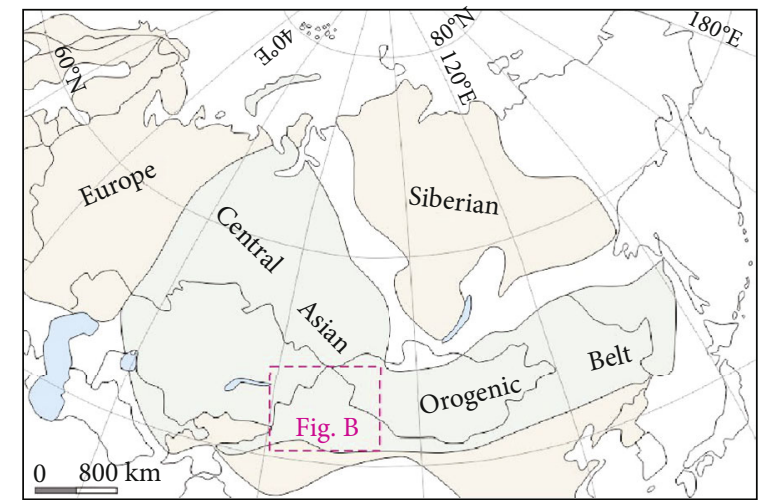

(a)

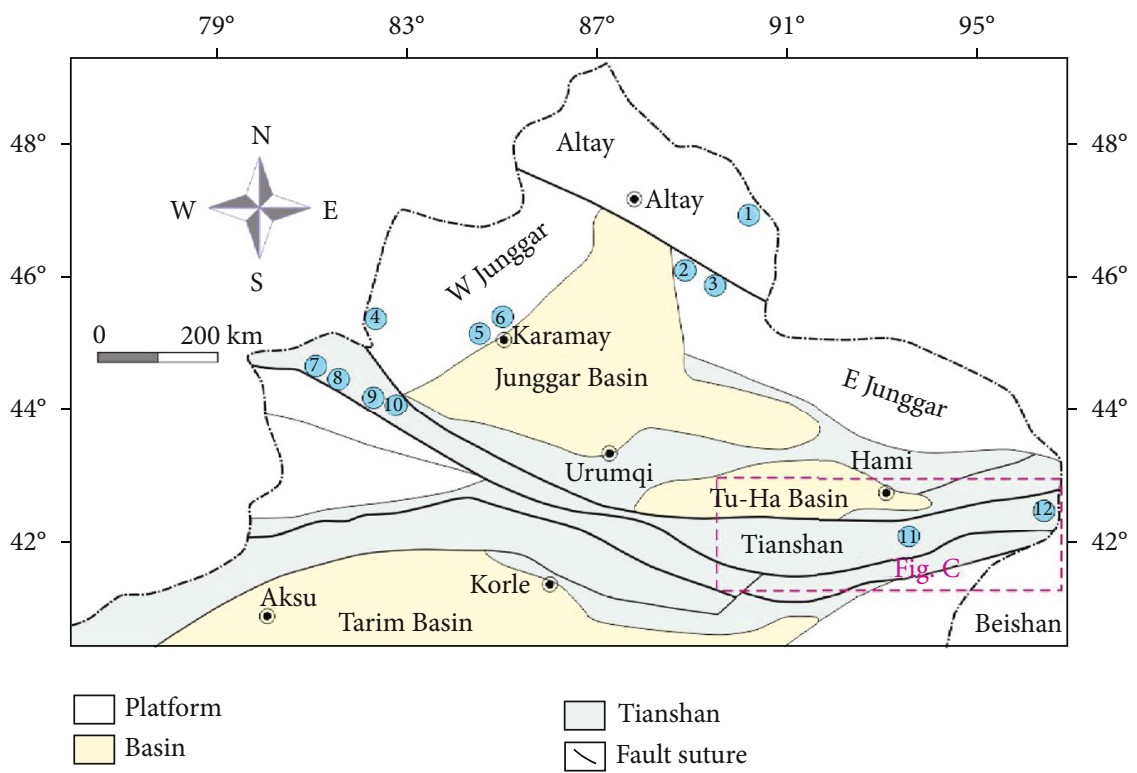

(b)

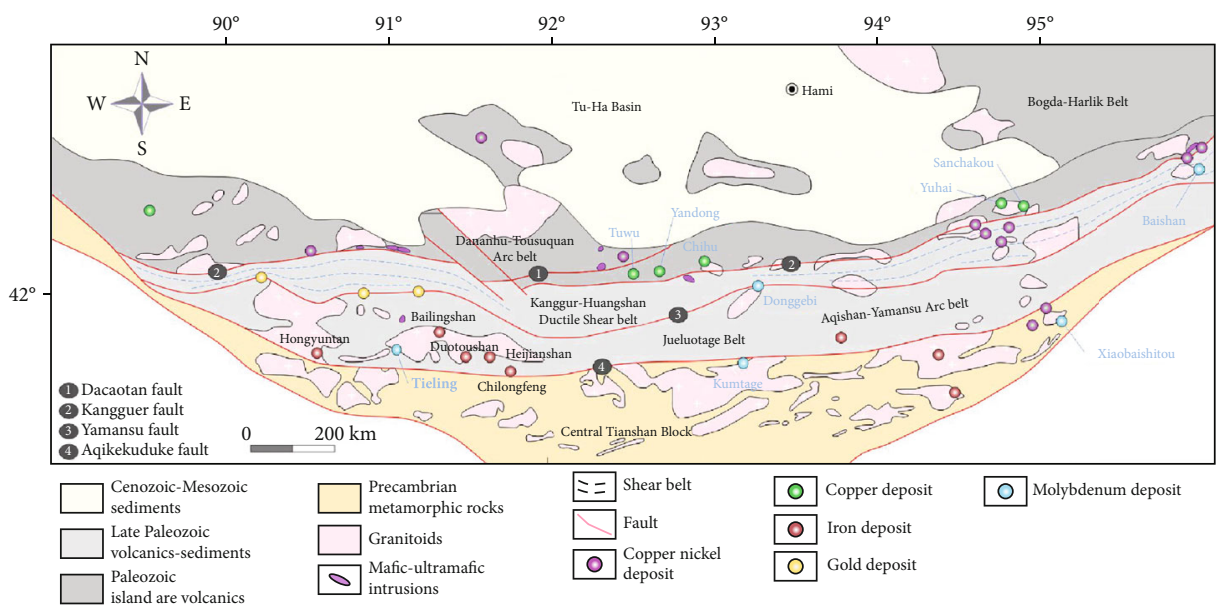

(c)

Figure 1: (a) Simplified map of the CAOB; (b) tectonic framework and representative deposits in northern Xinjiang; (c) simplified geological map of the eastern Tianshan showing the distribution of representative deposits (modified from Wang et al. [16]). 1: Asikaerte; 2: Suoerkuduke; 3: Yulekenhalasu; 4: Suyunhe; 5: Baogutu; 6: Hongyuan; 7: Dabate; 8: Kekesai; 9: Lailisigaoer; 10: Kendenggaoer; 11: Donggebi; 12: Baishan. 


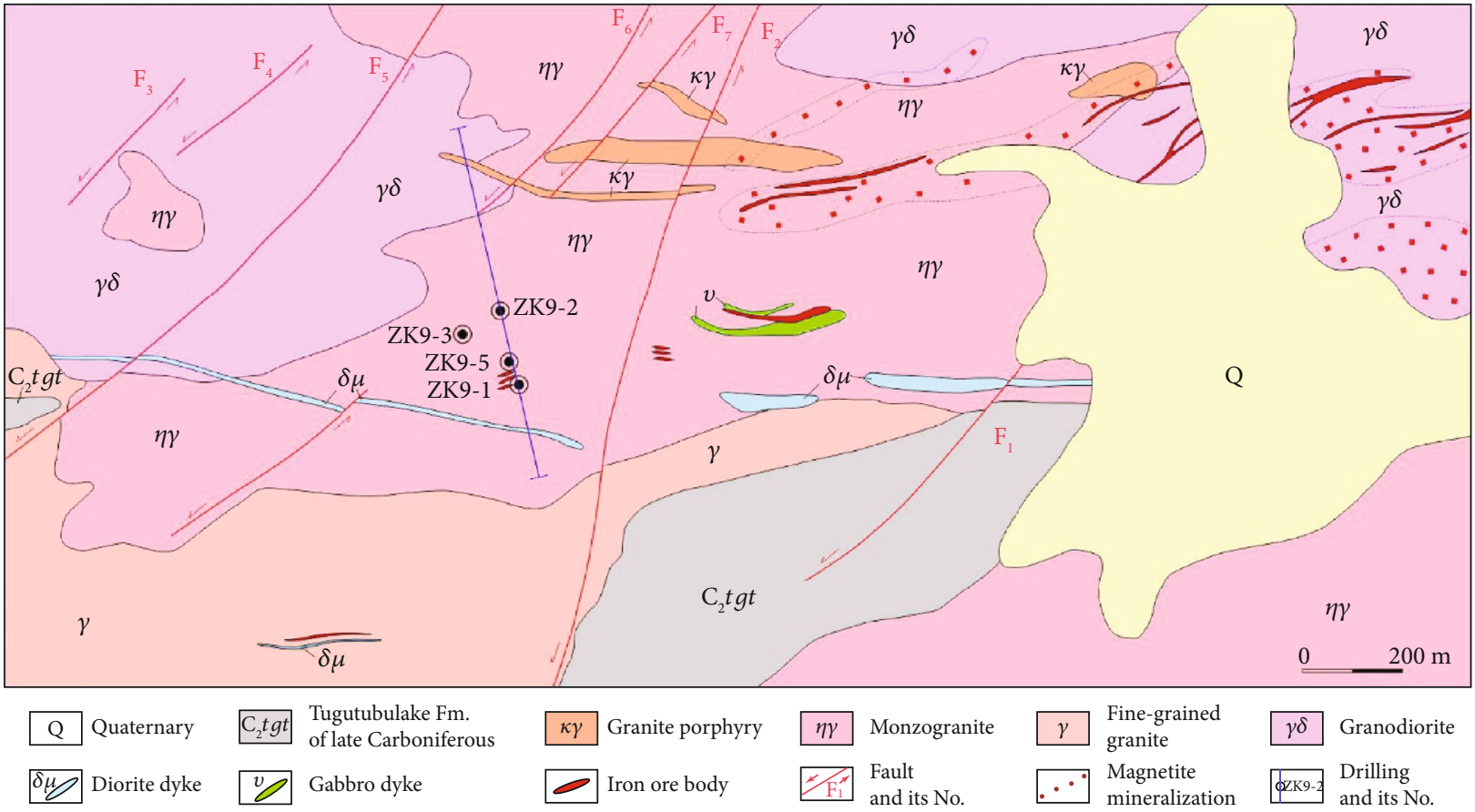

Figure 2: Simplified geological map of the Tieling Cu-Mo deposit (modified from Geological Survey Academy of Xinjiang, 2008).

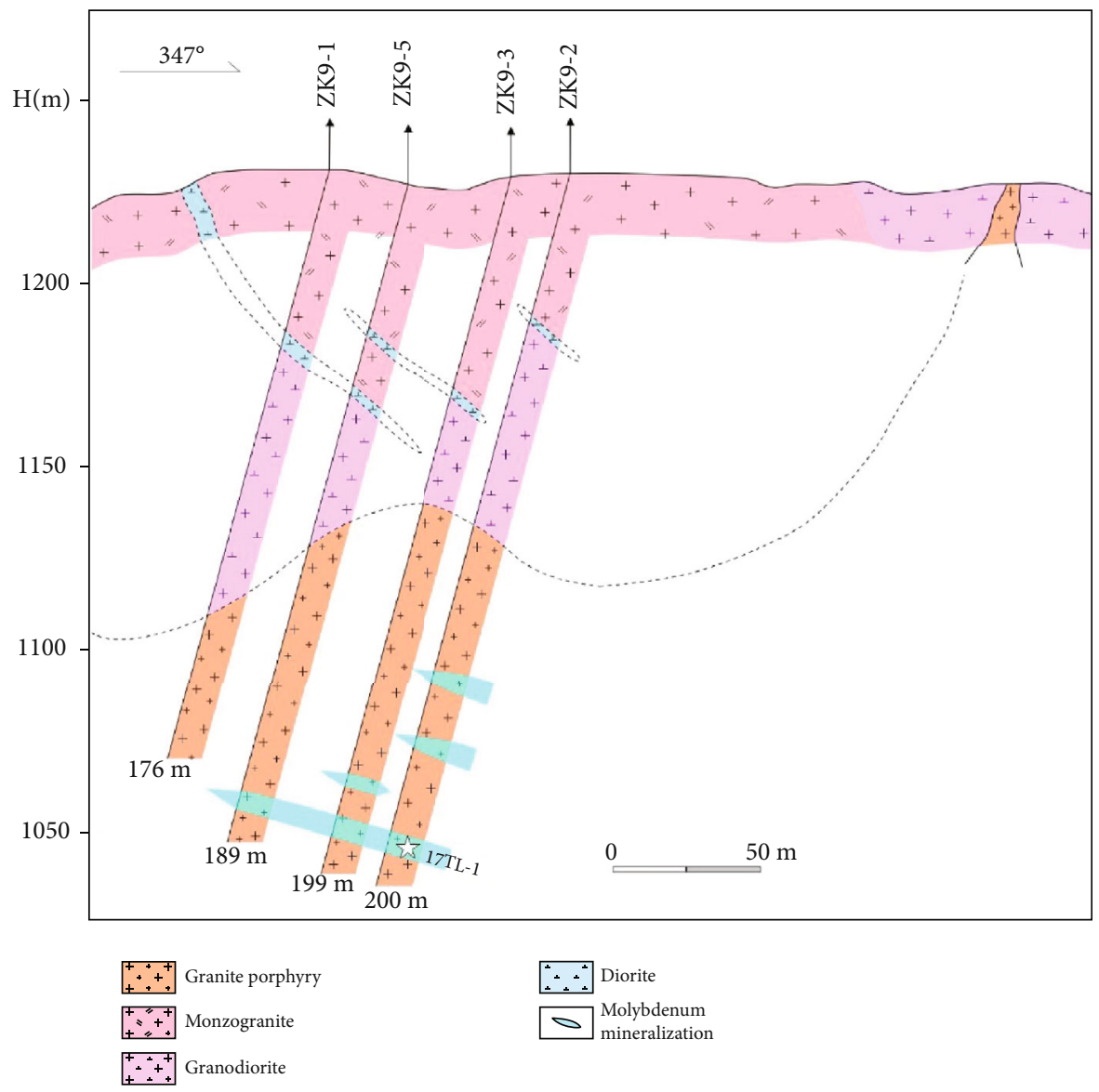

FIgURE 3: The geological section along the no. 9 exploration line on the map with lithologies and orebodies. 


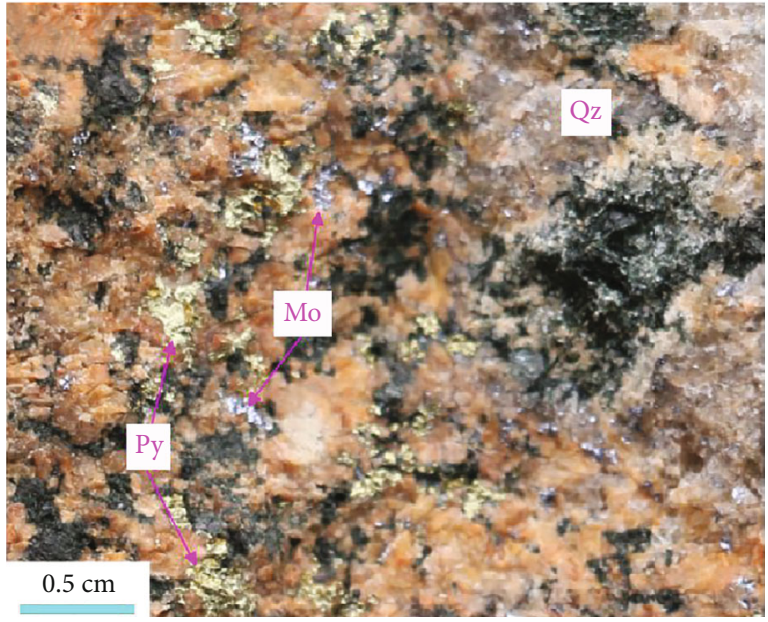

(a)

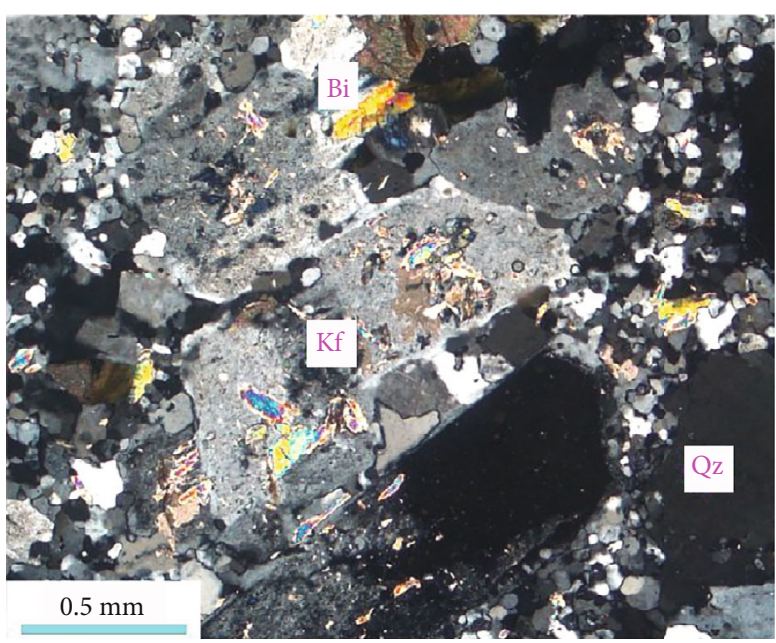

(c)

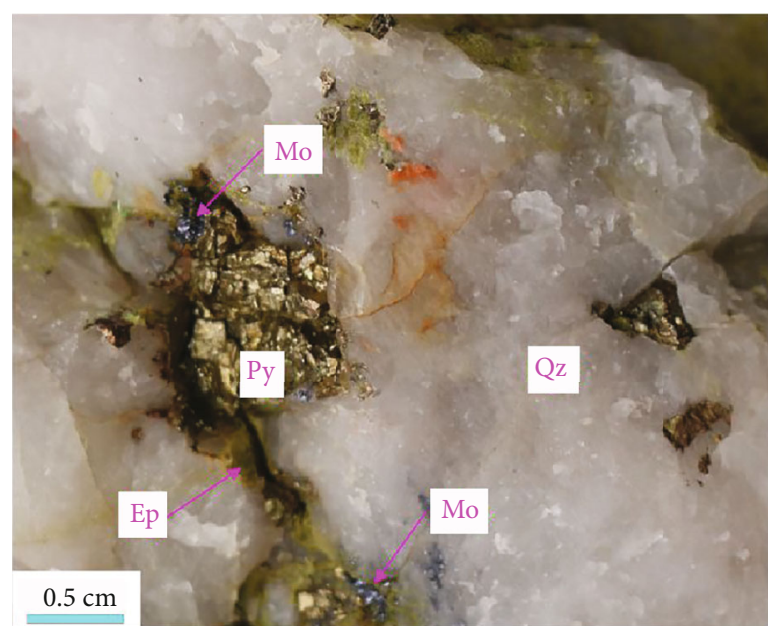

(e)

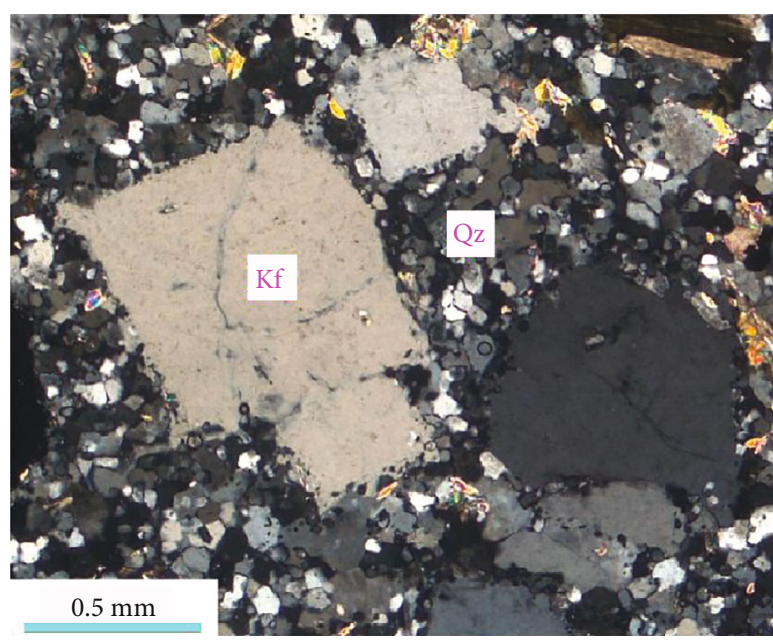

(b)

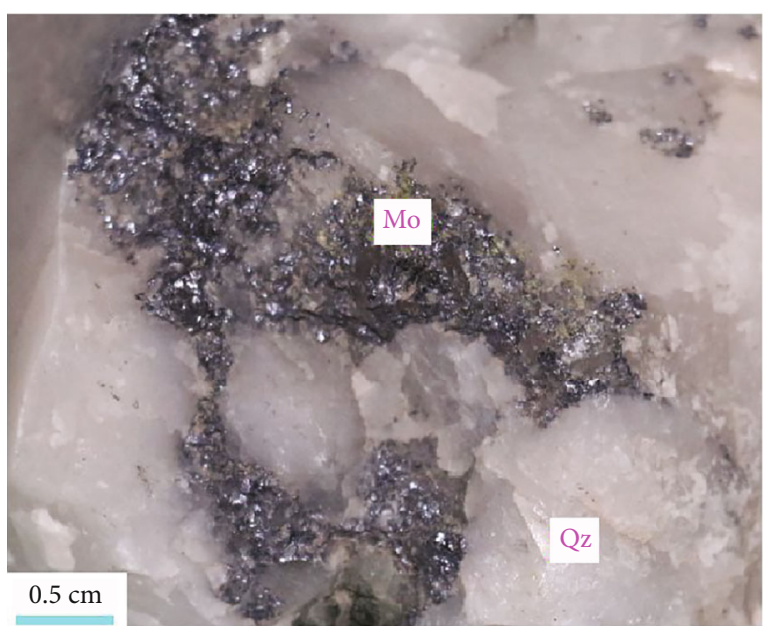

(d)

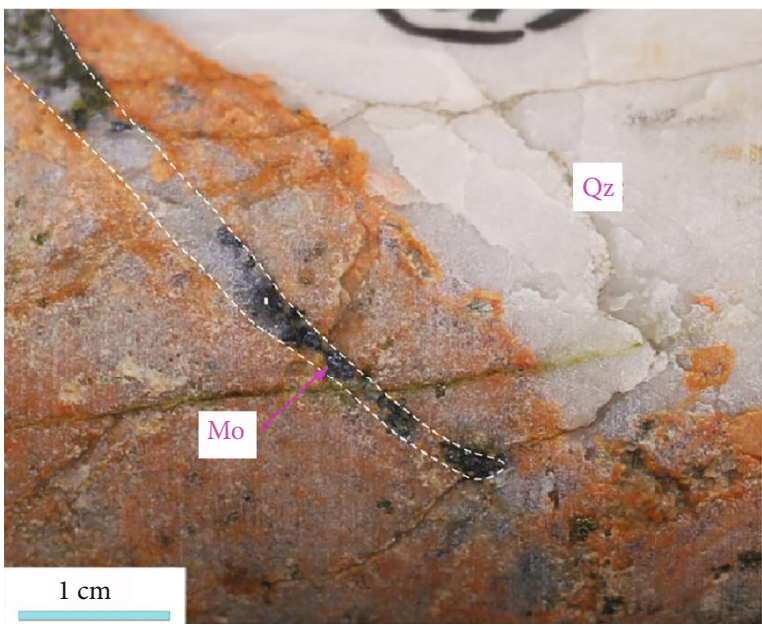

(f)

Figure 4: Continued. 


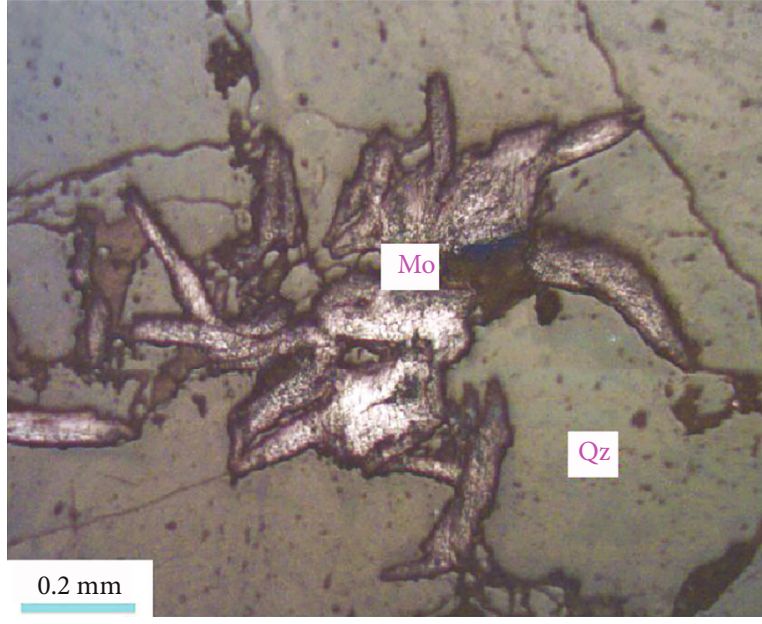

(g)

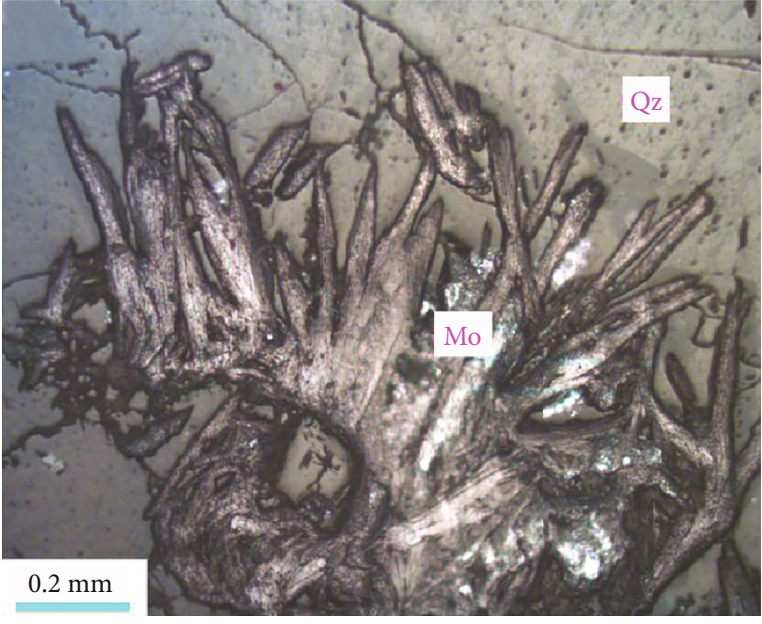

(h)

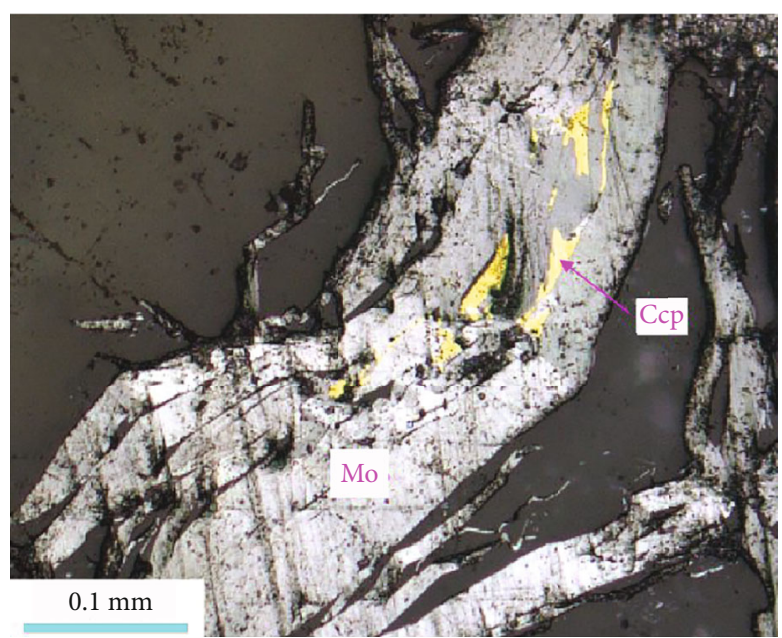

(i)

Figure 4: Characteristics of the rocks and ore minerals of the Tieling Cu-Mo deposit. (a) Disseminated molybdenite and pyrite in granite porphyry; (b) porphyritic texture of granite porphyry; (c) porphyritic texture of granite porphyry; (d) molybdenite in quartz vein; (e) molybdenite and pyrite coexisting in quartz vein and epidote fills in fissures; (f) veinlet molybdenite in granite porphyry; (g) molybdenite in quartz vein; (h) fascicular molybdenite in quartz vein; (i) molybdenite and chalcopyrite coexisting with quartz. Qz: quartz; Kf: K-feldspar; Ep: epidote; Bi: biotite; Mo: molybdenite; Py: pyrite; Ccp: chalcopyrite.

surrounding rock shows spatial zonation. From the granite porphyry to the surrounding rock, the alteration varies from a potassium silicate zone to a sericitization zone and finally a propylitization zone.

Based on field and microscopic observation of the mineralogy and the textural and paragenetic relationships of various hydrothermal minerals, three paragenetic stages of mineralization were identified in the Tieling deposit (Figure 5). These sequences are quartz+K-feldspar+pyrite +molybdenite \pm magnetite (stage I), quartz+molybdenite +pyrite+chalcopyrite (stage II), and quartz+pyrite+epidote \pm molybdenite \pm chlorite (stage III).

\section{Sampling and Analytical Methods}

4.1. Zircon $\mathrm{U}-\mathrm{Pb}$ Isotopes. The zircon $\mathrm{U}-\mathrm{Pb}$ isotope samples were collected from bearing molybdenite granite porphyry at a depth of $188 \mathrm{~m}$ in drill hole no. ZK9-2. Zircon grains

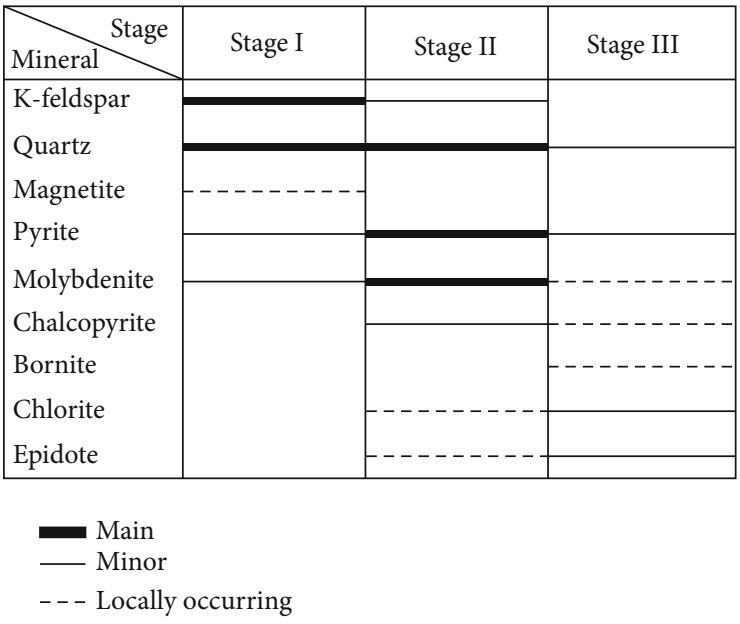

Figure 5: Paragenetic sequence of the Tieling $\mathrm{Cu}-\mathrm{Mo}$ deposit. 
were separated using heavy liquid and magnetic techniques, hand-picked under a binocular microscope, and mounted in epoxy resin. The internal texture of the zircons (including zoning, structures, and fractures) was characterized via cathodoluminescence (CL) imaging using a CAMECA electron microprobe at Yujin Technology Co., Ltd. U-Pb isotope analysis was performed at the State Key Laboratory of Mineral Deposits Research, Nanjing University, using an Agilent 7500a laser ablation system coupled with an iCAP RQ ICPMS. The analytical spot size, laser frequency, and energy density were $32 \mathrm{~mm}, 5 \mathrm{~Hz}$, and $6.5 \mathrm{~J} / \mathrm{cm}^{2}$, respectively. The analytical drift of the $\mathrm{U}-\mathrm{Th}-\mathrm{Pb}$ isotopic ratios was corrected using linear interpolation (with time) for every twelve analyses based on the signal variations of the zircon standard GJ1. Weighted mean age calculations and concordia diagrams were processed using ISOPLOT software [43].

\subsection{Fluid Inclusion Microthermometry and Laser Raman} Spectroscopy. The mineral assemblage and its paragenetic sequence were observed in the field and under the microscope for dividing three metallogenic stages. However, due to the low degree of exploration, we did not collect representative stage I samples for fluid inclusion study. Therefore, five samples comprising quartz veins of the stage II and stage III were selected, of which samples 20TL-3-78, 20TL-3-80, 20TL-3-83, and 20TL-3-87 were collected at depths of $78 \mathrm{~m}, 80 \mathrm{~m}, 83 \mathrm{~m}$, and $87 \mathrm{~m}$ in drill hole no. ZK9-3, respectively. Sample 20TL-2-167 was collected at a depth of $167 \mathrm{~m}$ in drill hole no. ZK9-2.

Fluid inclusion analyses were carried out at the Laboratory of Mineralization and Dynamics, Chang'an University, Xi'an, China, using the fluid inclusion assemblage (FIA). Microthermometric measurements were conducted using a Linkam THMSG 600 heating-freezing stage mounted on a Leica DMR microscope. The estimated accuracies of the freezing and heating measurements were $\pm 0.1^{\circ} \mathrm{C}$ from $-100^{\circ} \mathrm{C}$ to $25^{\circ} \mathrm{C}, \pm 1^{\circ} \mathrm{C}$ from $25^{\circ} \mathrm{C}$ to $400^{\circ} \mathrm{C}$, and $\pm 2^{\circ} \mathrm{C}$ above $400^{\circ} \mathrm{C}$. Heating and freezing rates were generally $0.2-$ $5^{\circ} \mathrm{C} / \mathrm{min}$ and were reduced to $0.2^{\circ} \mathrm{C} / \mathrm{min}$ near the temperatures of phase change. The salinity of aqueous fluid inclusions was estimated using equations for the $\mathrm{NaCl}-\mathrm{H}_{2} \mathrm{O}$ system provided by Bodnar [44]. The density of the oreforming fluid was estimated using data provided by Liu and Shen [45]. Volatile components of representative fluid inclusions were identified using a HORIBA HR Evolution $800 \mathrm{~mm}$ laser Raman spectrometer at the same institution. The laser wavelength was $532 \mathrm{~nm}$, and the single spectrum collection time was $2 \mathrm{~s}$. The Raman shift ranged from $100 \mathrm{~cm}^{-1}$ to $4000 \mathrm{~cm}^{-1}$. The spectrum resolution was $\pm 2 \mathrm{~cm}^{-}$ ${ }^{1}$ with a beam size of $1 \mu \mathrm{m}$. The instrumental setting was kept constant during all analyses.

4.3. H-O-S Isotopic Systematics. Five quartz samples from stage II and stage III were analysed for $\mathrm{O}$ (quartz) and $\mathrm{H}$ (water from fluid inclusions) isotopes. Their acquisition location corresponds to that of the fluid inclusions. Seven pyrite samples and one chalcopyrite sample were analysed for $\mathrm{S}$ isotopes. Of these, samples 20TL-1-160 and 20TL-1166 of stage I were collected from $160 \mathrm{~m}$ and $166 \mathrm{~m}$ drilling cores underground in drill hole no. ZK9-1, respectively. Samples 20TL-3-78, 20TL-3-87, 20TL-2-26, and 20TL-5-54 of stage II were collected from $78 \mathrm{~m}, 87 \mathrm{~m}, 26 \mathrm{~m}$, and $54 \mathrm{~m}$ drilling cores underground in drill hole nos. ZK9-3, ZK9-2, and ZK9-5, respectively. Sample 20TL-2-167 was collected from a $167 \mathrm{~m}$ drilling core underground in drill hole no. ZK9-2. Samples 20TL-3-83 of stage III were collected from an $83 \mathrm{~m}$ drilling core underground in drill hole no. ZK9-3.

The $\delta \mathrm{D}$ values of water from fluid inclusions and the $\delta^{18} \mathrm{O}$ values of their host minerals were measured at the Beijing Research Institute of Uranium Geology, China. The water contained in the fluid inclusions of the host minerals was released via thermal decrepitation at $400^{\circ} \mathrm{C}$ and then collected, frozen, and purified. Then, using reductive zinc, we replaced and released the hydrogen in the water to perform mass spectrometry. The analytical precision of the $\delta \mathrm{D}$ values was within $\pm 2 \%$ o $(1 \sigma)$ and that of the $\delta^{18} \mathrm{O}$ values was within $\pm 0.2 \%(2 \sigma)$. The $\delta^{18} \mathrm{O}$ values in quartz water $\left(\alpha_{\text {quartz water }}\right)$ were calculated from the $\delta^{18} \mathrm{O}_{\text {quartz }}$ values of the analysed quartz by using the fractionation equation $1000 \operatorname{In} \alpha_{\text {quartz water }}=\left(3.38 \times 10^{6}\right) T^{-2}-3.40$, where $T$ is the temperature in Kelvin [46], and the average corrected temperature of fluid inclusion was used to calculate the $\delta^{18} \mathrm{O}_{\text {water }}$ value.

We separated the pyrite and chalcopyrite samples from the disseminations, veins, and crumb ores for sulfur isotope analysis. Sulfur isotopic analyses were carried out on a MAT253 mass spectrometer at the Beijing Research Institute of Uranium Geology, China. Seven pyrite samples and one chalcopyrite sample were converted to $\mathrm{SO}_{2}$ under hightemperature vacuum conditions. The $\delta^{34} \mathrm{~S}$ values were measured on a DELTA V plus gas isotope mass spectrometer. Sulfur isotope values are reported in per mil relative following the Vienna Canyon Diablo Troilite (V-CDT) standard, and the analytical uncertainty was within $\pm 0.2 \%$ for $\delta^{34}$ S. The equilibrium temperature of sulfur isotopes was calculated from symbiotic sulfides by using the fractionation equation $1000 \operatorname{In} \alpha_{\mathrm{Py}-\mathrm{Ccp}}=0.45 \times 10^{6} / T^{-2}$, where $T$ is the temperature in Kelvin [47].

\section{Results}

5.1. Zircon $U-P b$ Isotopes. The granite porphyry (TL1) was dated by zircon U-Pb analysis. LA-ICP-MS zircon U-Pb dating results are summarized in Table 1 , and representative CL images of zircon grains from these rocks are shown in Figure 6. All the analysed zircons are prismatic, euhedral, and colourless, and most of them show oscillatory zoning patterns, which imply a magmatic origin. The analysed zircons have variable $U$ (37-433 ppm) and Th (164-547 ppm) contents, with $\mathrm{Th} / \mathrm{U}$ ratios ranging from 0.22 to 0.81 (mainly $>0.1$ ). Twenty-four zircon grains from the granite porphyry samples define a narrow range with ${ }^{206} \mathrm{~Pb} /{ }^{238} \mathrm{U}$ ages of 296 to $298 \mathrm{Ma}$, yielding a concordant age of $298.4 \pm 0.7 \mathrm{Ma}$ $(\mathrm{MSWD}=28$; Figure $7(\mathrm{a}))$, with a weighted mean age of $297.0 \pm 1.6 \mathrm{Ma}(\mathrm{MSWD}=0.027$; Figure $7(\mathrm{~b}))$.

5.2. Fluid Inclusions. Based on phase characteristics at room temperature, phase transitions during heating and cooling, 
TABLE 1: LA-ICP-MS U-Pb data of zircon grains from granite porphyry of the Tieling deposit.

\begin{tabular}{|c|c|c|c|c|c|c|c|c|c|c|c|c|c|c|c|}
\hline \multirow[b]{2}{*}{ Spot } & \multirow{2}{*}{$\begin{array}{c}\text { Th } \\
(\mathrm{ppm})\end{array}$} & \multirow{2}{*}{$\begin{array}{c}\mathrm{U} \\
(\mathrm{ppm})\end{array}$} & \multirow{2}{*}{$\begin{array}{c}\text { Th/ } \\
\text { U }\end{array}$} & \multicolumn{2}{|c|}{${ }^{207} \mathrm{~Pb} /{ }^{206} \mathrm{~Pb}$} & \multicolumn{2}{|c|}{${ }^{207} \mathrm{~Pb} /{ }^{235} \mathrm{U}$} & \multicolumn{2}{|c|}{${ }^{206} \mathrm{~Pb} /{ }^{238} \mathrm{U}$} & \multicolumn{2}{|c|}{${ }^{207} \mathrm{~Pb} /{ }^{206} \mathrm{~Pb}$} & \multicolumn{2}{|c|}{${ }^{207} \mathrm{~Pb} /{ }^{235} \mathrm{U}$} & \multicolumn{2}{|c|}{${ }^{206} \mathrm{~Pb} /{ }^{238} \mathrm{U}$} \\
\hline & & & & Ratio & $1 \sigma$ & Ratio & $1 \sigma$ & Ratio & $1 \sigma$ & $\begin{array}{l}\text { Age } \\
\text { (Ma) }\end{array}$ & $1 \sigma$ & $\begin{array}{l}\text { Age } \\
(\mathrm{Ma})\end{array}$ & $1 \sigma$ & $\begin{array}{l}\text { Age } \\
\text { (Ma) }\end{array}$ & $1 \sigma$ \\
\hline TL1-1 & 125 & 290 & 0.43 & 0.05308 & 0.00097 & 0.34501 & 0.00662 & 0.04715 & 0.00060 & 332 & 42 & 301 & 5 & 297 & 4 \\
\hline TL1-2 & 114 & 267 & 0.43 & 0.05142 & 0.00096 & 0.33475 & 0.00654 & 0.04723 & 0.00060 & 260 & 44 & 293 & 5 & 297 & 4 \\
\hline TL1-3 & 240 & 430 & 0.56 & 0.05241 & 0.00092 & 0.33954 & 0.00631 & 0.04699 & 0.00060 & 303 & 41 & 297 & 5 & 296 & \\
\hline TL1-4 & 131 & 314 & 0.42 & 0.05240 & 0.00094 & 0.33953 & 0.00645 & 0.04700 & 0.00060 & 303 & 42 & 297 & 5 & 296 & \\
\hline TL1-5 & 325 & 445 & 0.73 & 0.05252 & 0.00092 & 0.34024 & 0.00631 & 0.04699 & 0.00060 & 308 & 41 & 297 & 5 & 296 & \\
\hline TL1-6 & 120 & 286 & 0.42 & 0.05228 & 0.00097 & 0.34071 & 0.00661 & 0.04727 & 0.00060 & 298 & 43 & 298 & 5 & 298 & 4 \\
\hline TL1-7 & 118 & 283 & 0.42 & 0.05336 & 0.00106 & 0.34709 & 0.00715 & 0.04718 & 0.00061 & 344 & 46 & 303 & 5 & 297 & 4 \\
\hline TL1-8 & 87 & 222 & 0.39 & 0.05326 & 0.00103 & 0.34701 & 0.00703 & 0.04726 & 0.00061 & 340 & 45 & 302 & 5 & 298 & 4 \\
\hline TL1-9 & 433 & 543 & 0.80 & 0.05352 & 0.00089 & 0.34704 & 0.00624 & 0.04703 & 0.00061 & 351 & 38 & 302 & 5 & 296 & \\
\hline $\begin{array}{l}\text { TL1- } \\
10\end{array}$ & 169 & 351 & 0.48 & 0.05321 & 0.00085 & 0.34663 & 0.00606 & 0.04725 & 0.00061 & 338 & 37 & 302 & 5 & 298 & 4 \\
\hline $\begin{array}{l}\text { TL1- } \\
11\end{array}$ & 123 & 311 & 0.40 & 0.05453 & 0.00093 & 0.35556 & 0.00654 & 0.04729 & 0.00061 & 393 & 39 & 309 & 5 & 298 & 4 \\
\hline $\begin{array}{l}\text { TL1- } \\
12\end{array}$ & 74 & 197 & 0.38 & 0.05334 & 0.00105 & 0.34691 & 0.00721 & 0.04718 & 0.00062 & 343 & 46 & 302 & 5 & 297 & 4 \\
\hline $\begin{array}{l}\text { TL1- } \\
13\end{array}$ & 160 & 333 & 0.48 & 0.05445 & 0.00097 & 0.35422 & 0.00675 & 0.04719 & 0.00062 & 390 & 41 & 308 & 5 & 297 & 4 \\
\hline $\begin{array}{l}\text { TL1- } \\
14\end{array}$ & 286 & 547 & 0.52 & 0.05375 & 0.00080 & 0.34948 & 0.00576 & 0.04716 & 0.00061 & 361 & 34 & 304 & 4 & 297 & 4 \\
\hline $\begin{array}{l}\text { TL1- } \\
15\end{array}$ & 190 & 368 & 0.52 & 0.05497 & 0.00089 & 0.35743 & 0.00631 & 0.04716 & 0.00061 & 411 & 37 & 310 & 5 & 297 & 4 \\
\hline $\begin{array}{l}\text { TL1- } \\
16\end{array}$ & 115 & 277 & 0.42 & 0.05524 & 0.00094 & 0.35890 & 0.00659 & 0.04713 & 0.00061 & 422 & 39 & 311 & 5 & 297 & 4 \\
\hline $\begin{array}{l}\text { TL1- } \\
17\end{array}$ & 71 & 198 & 0.36 & 0.05304 & 0.00104 & 0.34557 & 0.00718 & 0.04726 & 0.00063 & 331 & 46 & 301 & 5 & 298 & 4 \\
\hline $\begin{array}{l}\text { TL1- } \\
18\end{array}$ & 76 & 210 & 0.36 & 0.05192 & 0.00097 & 0.33791 & 0.00673 & 0.04721 & 0.00063 & 282 & 44 & 296 & 5 & 297 & 4 \\
\hline $\begin{array}{l}\text { TL1- } \\
19\end{array}$ & 55 & 164 & 0.34 & 0.05330 & 0.00169 & 0.34612 & 0.00986 & 0.04709 & 0.00065 & 342 & 73 & 302 & 7 & 297 & 4 \\
\hline $\begin{array}{l}\text { TL1- } \\
20\end{array}$ & 72 & 179 & 0.40 & 0.05386 & 0.00113 & 0.34990 & 0.00773 & 0.04712 & 0.00063 & 365 & 48 & 305 & 6 & 297 & 4 \\
\hline $\begin{array}{l}\text { TL1- } \\
21\end{array}$ & 90 & 229 & 0.39 & 0.05264 & 0.00101 & 0.34278 & 0.00702 & 0.04723 & 0.00063 & 313 & 45 & 299 & 5 & 297 & 4 \\
\hline $\begin{array}{l}\text { TL1- } \\
22\end{array}$ & 112 & 242 & 0.46 & 0.05449 & 0.00105 & 0.35444 & 0.00723 & 0.04718 & 0.00063 & 391 & 44 & 308 & 5 & 297 & 4 \\
\hline $\begin{array}{l}\text { TL1- } \\
23\end{array}$ & 179 & 417 & 0.43 & 0.05491 & 0.00086 & 0.35730 & 0.00616 & 0.04720 & 0.00062 & 409 & 36 & 310 & 5 & 297 & 4 \\
\hline $\begin{array}{l}\text { TL1- } \\
24\end{array}$ & 154 & 390 & 0.39 & 0.05225 & 0.00085 & 0.33868 & 0.00601 & 0.04702 & 0.00062 & 296 & 38 & 296 & 5 & 296 & \\
\hline
\end{tabular}

and the results of laser Raman spectroscopy, fluid inclusions in the Tieling deposit mainly include liquid-rich inclusions (WL type). Fluid inclusions occurring as isolated inclusions, random distributions, or clusters are interpreted as primary features at various stages (Figure 8). Each cluster or group of fluid inclusions along growth zones was considered to represent an FIA. Fluid inclusions occurring in linear arrays along fractures or grain boundaries were considered to be secondary fluid inclusions, which were not analysed by microthermometry because they formed later with respect to mineralization. The inclusions are ovular, polygonal, and irregular, with diameters in the range of 3-18 $\mu \mathrm{m}$, mainly $5-10 \mu \mathrm{m}$, and contain gas bubbles that account for $10-40 \%$ of the total volume. These inclusions homogenize to the liquid phase when heated.

The microthermometric results and fluid inclusion parameters are shown in Table 2. For the fluid inclusions in quartz of stage II, the final ice melting temperatures of WL-type fluid inclusions range from -13.8 to $-4.5^{\circ} \mathrm{C}$ (with an average of $-9.1^{\circ} \mathrm{C}$ ), with corresponding salinities of 7.2 to $17.2 \mathrm{wt} \% \mathrm{NaCl}$ equiv. (with an average of $12.9 \mathrm{wt} \% \mathrm{NaCl}$ equiv.). The homogenization temperatures of fluid 
Granite porphyry (17LT1)

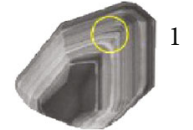

$297 \pm 4 \mathrm{Ma}$

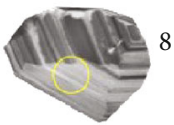

$298 \pm 4 \mathrm{Ma}$
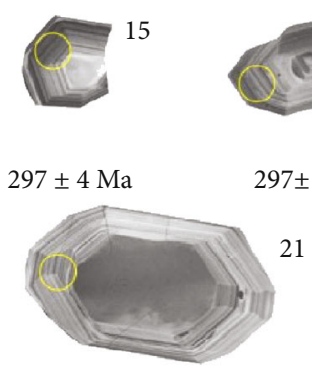

$297 \pm 4 \mathrm{Ma}$

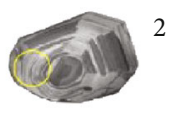

$297 \pm 4 \mathrm{Ma}$

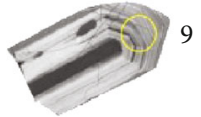

$296 \pm 4 \mathrm{Ma}$

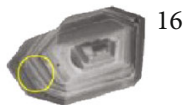

$297 \pm 4 \mathrm{Ma}$

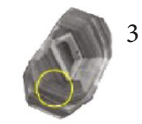

$296 \pm 4 \mathrm{Ma}$
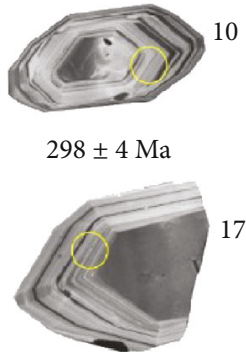

$298 \pm 4 \mathrm{Ma}$

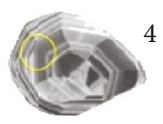

$296 \pm 4 \mathrm{Ma}$

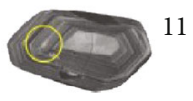

$298 \pm 4 \mathrm{Ma}$

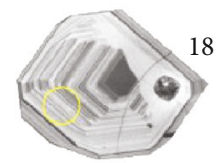

$297 \pm 4 \mathrm{Ma}$

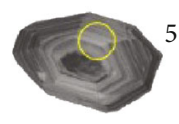

$296 \pm 4 \mathrm{Ma}$

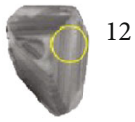

$297 \pm 4 \mathrm{Ma}$

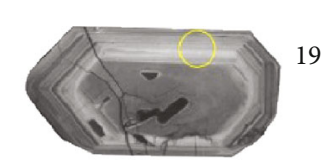

$297 \pm 4 \mathrm{Ma}$

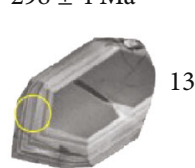

13

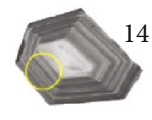

$297 \pm 4 \mathrm{Ma}$

Figure 6: Cathodoluminescence (CL) images of representative zircons from granite porphyry in the Tieling deposit.

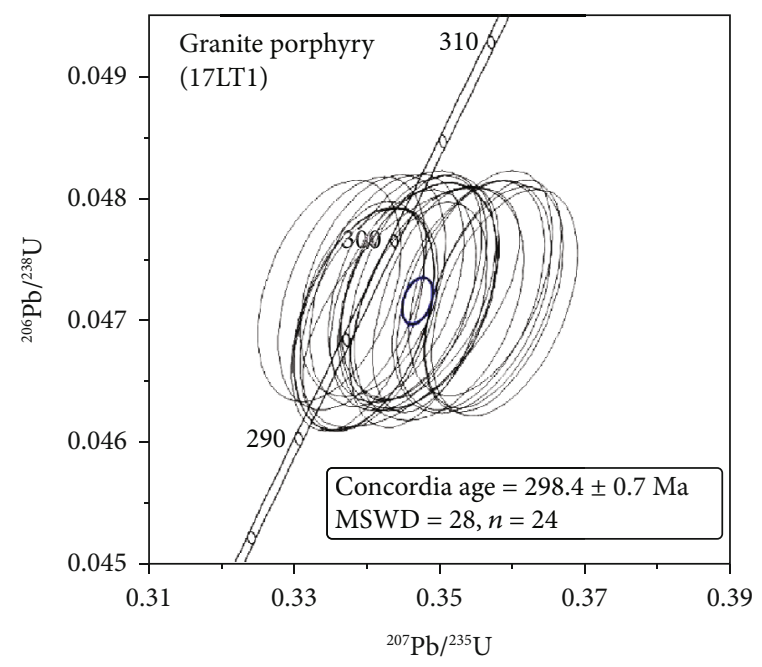

(a)

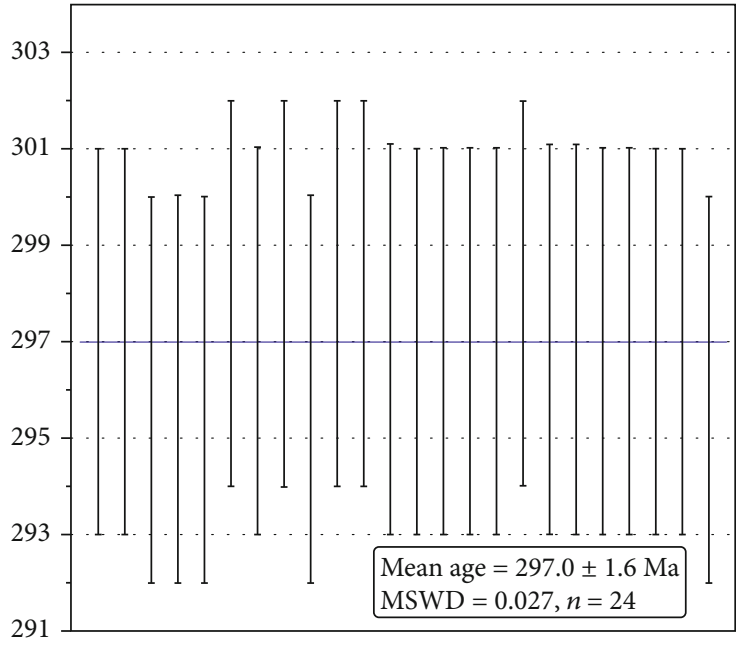

(b)

Figure 7: The U-Pb concordant diagram and the weighted average age of zircons from granite porphyry in the Tieling deposit.

inclusions range from 157 to $262^{\circ} \mathrm{C}$ (with an average of $193.1^{\circ} \mathrm{C}$ ), and the fluid densities are 0.897 to $1.025 \mathrm{~g} / \mathrm{cm}^{3}$. For the fluid inclusions in quartz (samples 20TL-3-83) of stage III, the final ice melting temperature of WL-type fluid inclusions is -6.3 to $-3.6^{\circ} \mathrm{C}$ (with an average of $-5.0^{\circ} \mathrm{C}$ ), the salinity is 5.9 to $9.6 \mathrm{wt} \% \mathrm{NaCl}$ equiv. (with an average of $7.9 \mathrm{wt} \% \mathrm{NaCl}$ equiv.), the homogenization temperatures of fluid inclusions range from 135 to $173^{\circ} \mathrm{C}$ (with an average of $154.2^{\circ} \mathrm{C}$ ), and the fluid densities are 0.959 to $0.995 \mathrm{~g} / \mathrm{cm}^{3}$. Previous studies indicate that the emplacement depths for porphyry deposits are generally around $3-5 \mathrm{~km}$
[48]. Due to lack of pressure data for this deposit, we used the lithostatic pressure at $5 \mathrm{~km}$ to calculate the entrapment temperatures of the analysed fluid inclusions. The fluid lithostatic pressure of the Tieling deposit can be estimated to be 1350 bar. Then, the average ore-forming temperatures of stage II and stage III were corrected to range from $268^{\circ} \mathrm{C}$ to $225^{\circ} \mathrm{C}$ (Figure 9).

We conducted a laser Raman spectroscopic speak scan of the gas-phase components in the fluid inclusions of quartz from the Tieling deposit. The results of representative laser Raman spectroscopic analyses are shown in Figure 10. The 


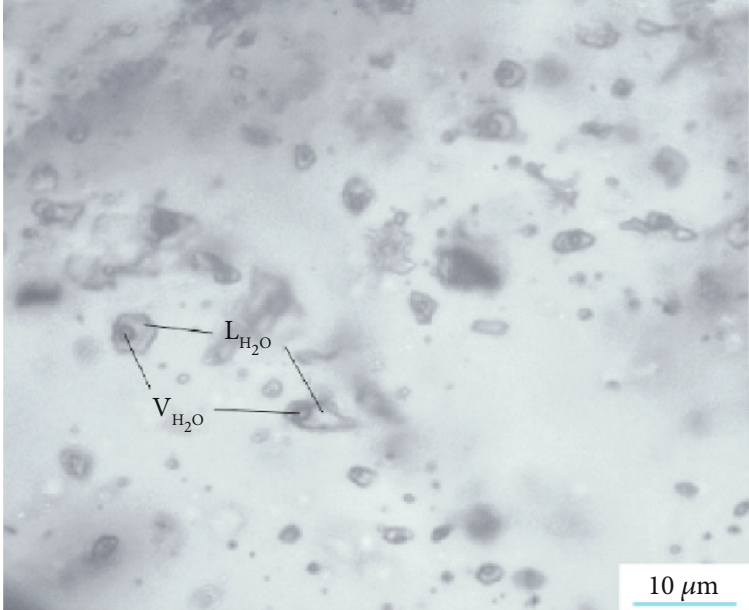

(a)

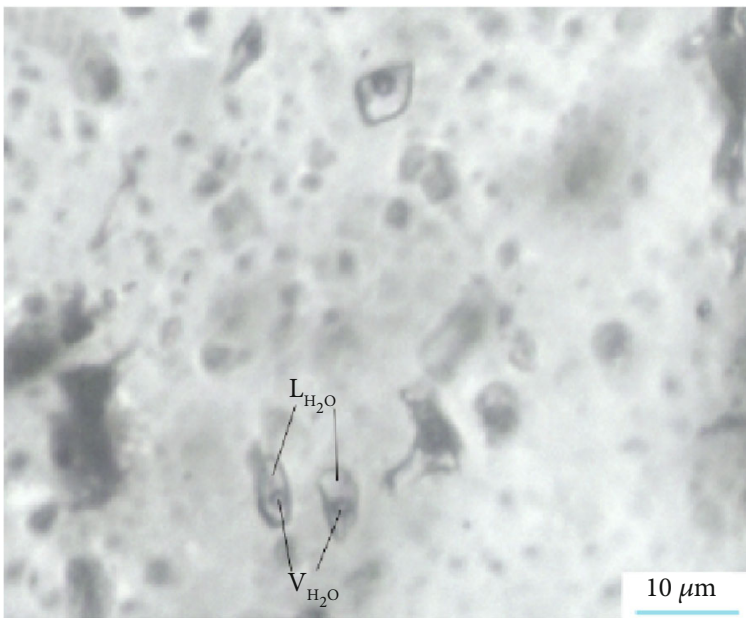

(c)

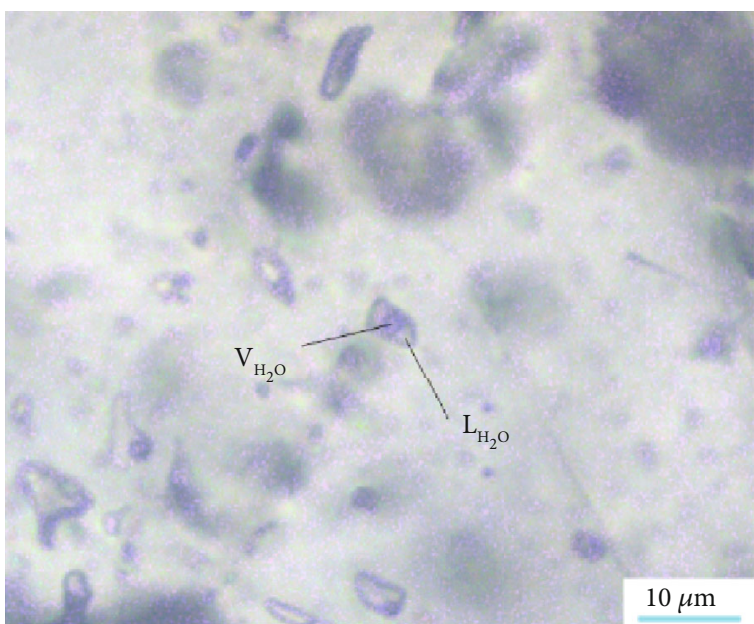

(e)

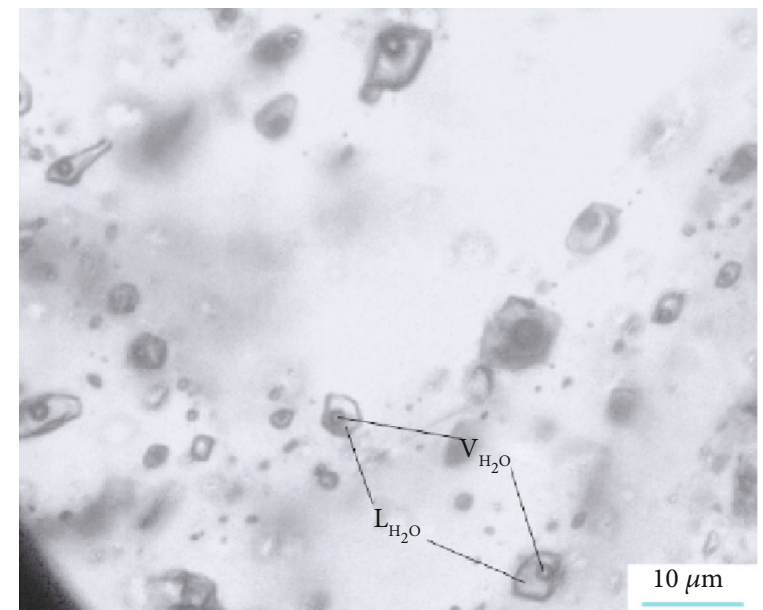

(b)

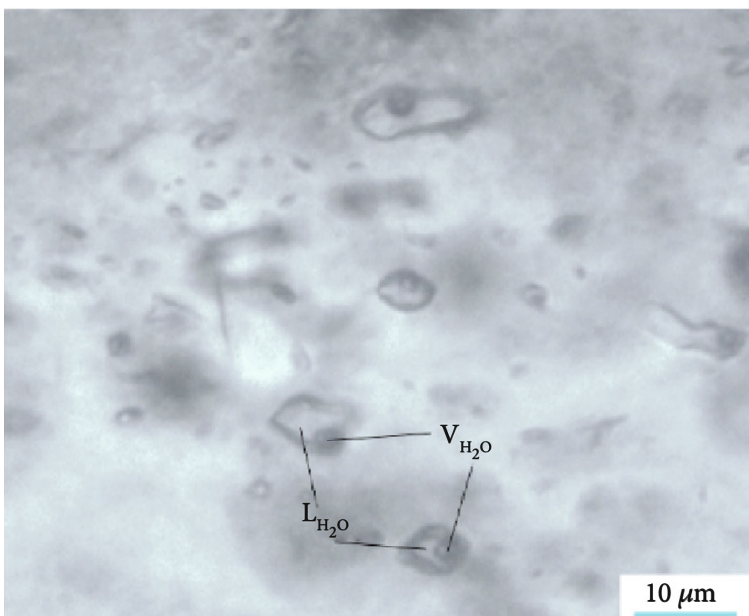

(d)

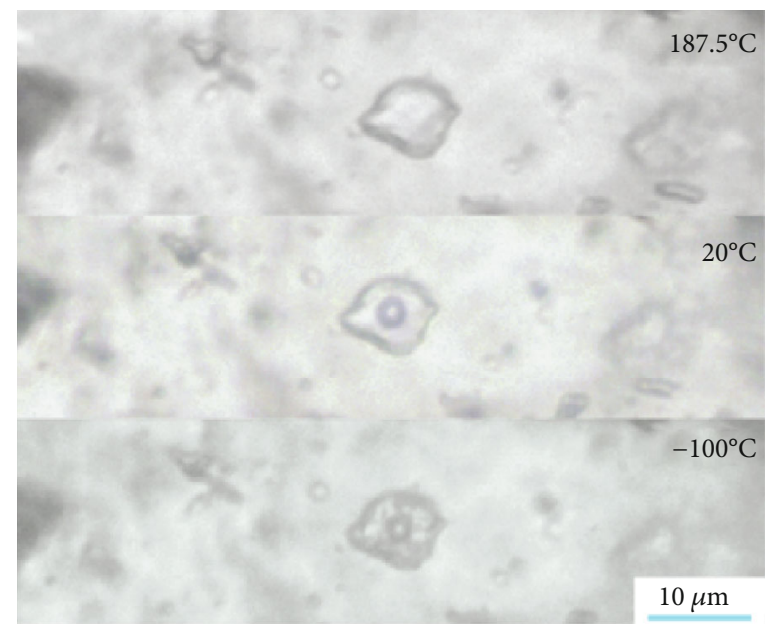

(f)

FIGURE 8: Photomicrographs of representative fluid inclusions in quartz crystals from the Tieling Cu-Mo deposit: (a) liquid-rich inclusions in quartz of stage II; (b) liquid-rich inclusions in quartz of stage II; (c) liquid-rich inclusions in quartz of stage II; (d) liquid-rich inclusions in quartz of stage II; (e) liquid-rich inclusions in quartz of stage III; and (f) morphology of liquid-rich inclusions in quartz at different temperatures. $\mathrm{L}_{\mathrm{H} 2 \mathrm{O}}$ : liquid-phase $\mathrm{H}_{2} \mathrm{O} ; \mathrm{V}_{\mathrm{H} 2 \mathrm{O}}$ : vapor-phase $\mathrm{H}_{2} \mathrm{O}$. 
TABLE 2: Microthermometry data and relative parameters of fluid inclusions in the Tieling deposit.

\begin{tabular}{|c|c|c|c|c|c|c|c|c|c|c|c|}
\hline $\begin{array}{l}\text { Sample } \\
\text { no. }\end{array}$ & Location & Mineral & Type & $\operatorname{Size}(\mu \mathrm{m})$ & $\begin{array}{c}V \\
(\%)\end{array}$ & No. & $\begin{array}{c}T_{\mathrm{m}(\text { ice })} \\
\left({ }^{\circ} \mathrm{C}\right)\end{array}$ & $T_{\mathrm{h}}\left({ }^{\circ} \mathrm{C}\right)$ & $T_{\mathrm{c}}\left({ }^{\circ} \mathrm{C}\right)$ & $\begin{array}{c}\text { Salinity (\% } \mathrm{NaCl} \\
\text { equiv.) }\end{array}$ & $\begin{array}{l}\text { Density } \\
\left(\mathrm{g} / \mathrm{cm}^{3}\right)\end{array}$ \\
\hline \multicolumn{12}{|c|}{ Quartz of stage II } \\
\hline $\begin{array}{l}20 \mathrm{TL}-3- \\
78\end{array}$ & $\begin{array}{c}\text { ZK9-3/ } \\
78 \mathrm{~m}\end{array}$ & Quartz+pyrite & WL & $5-14$ & $\begin{array}{c}10- \\
60\end{array}$ & 28 & $\begin{array}{c}-13.2 \text { to } \\
-6.7\end{array}$ & $\begin{array}{c}182 \text { to } \\
262\end{array}$ & $\begin{array}{l}251 \text { to } \\
355\end{array}$ & 10.1 to 17.2 & $\begin{array}{c}0.897 \text { to } \\
1.013\end{array}$ \\
\hline $\begin{array}{l}20 \text { TL-3- } \\
80\end{array}$ & $\begin{array}{l}\text { ZK9-3/ } \\
80 \mathrm{~m}\end{array}$ & $\begin{array}{l}\text { Quartz+pyrite } \\
\text { +chalcopyrite }\end{array}$ & WL & $6-15$ & $\begin{array}{l}10- \\
45\end{array}$ & 16 & $\begin{array}{c}-12.8 \text { to } \\
-7.2\end{array}$ & $\begin{array}{c}157 \text { to } \\
242\end{array}$ & $\begin{array}{c}224 \text { to } \\
328\end{array}$ & 10.7 to 16.8 & $\begin{array}{c}0.934 \text { to } \\
1.025\end{array}$ \\
\hline $\begin{array}{l}20 \mathrm{TL}-3- \\
87\end{array}$ & $\begin{array}{c}\text { ZK9-3/ } \\
87 \mathrm{~m}\end{array}$ & $\begin{array}{l}\text { Quartz+pyrite } \\
\text { +molybdenite }\end{array}$ & WL & $5-15$ & $\begin{array}{c}10- \\
40\end{array}$ & 23 & $\begin{array}{c}-13.8 \text { to } \\
-4.5\end{array}$ & $\begin{array}{c}168 \text { to } \\
222\end{array}$ & $\begin{array}{c}237 \text { to } \\
301\end{array}$ & 7.2 to 17.1 & $\begin{array}{c}0.922 \text { to } \\
1.019\end{array}$ \\
\hline $\begin{array}{l}20 \mathrm{TL}-2- \\
167\end{array}$ & $\begin{array}{c}\text { ZK9-2/ } \\
167 \mathrm{~m}\end{array}$ & Quartz+molybdenite & WL & $6-12$ & $\begin{array}{c}10- \\
40\end{array}$ & 21 & $\begin{array}{c}-12.8 \text { to } \\
-6.1\end{array}$ & $\begin{array}{l}165 \text { to } \\
250\end{array}$ & $\begin{array}{c}232 \text { to } \\
340\end{array}$ & 9.3 to 16.8 & $\begin{array}{c}0.906 \text { to } \\
0.999\end{array}$ \\
\hline \multicolumn{12}{|c|}{ Quartz of stage III } \\
\hline $\begin{array}{l}20 \text { TL-3- } \\
83\end{array}$ & $\begin{array}{c}\text { ZK9-3/ } \\
83 \mathrm{~m}\end{array}$ & Quartz & WL & $3-8$ & $\begin{array}{l}10- \\
20\end{array}$ & 21 & $\begin{array}{c}-6.3 \text { to } \\
-3.6\end{array}$ & $\begin{array}{c}135 \text { to } \\
173\end{array}$ & $\begin{array}{c}201 \text { to } \\
246\end{array}$ & 5.9 to 9.6 & $\begin{array}{c}0.959 \text { to } \\
0.995\end{array}$ \\
\hline
\end{tabular}

$T_{\mathrm{m} \text { (ice) }}$ : final melting temperature of ice; $T_{\mathrm{h}}$ : total homogenization temperature; $T_{\mathrm{c}}$ : corrected temperature; $V$ : percentage of bubble volume.
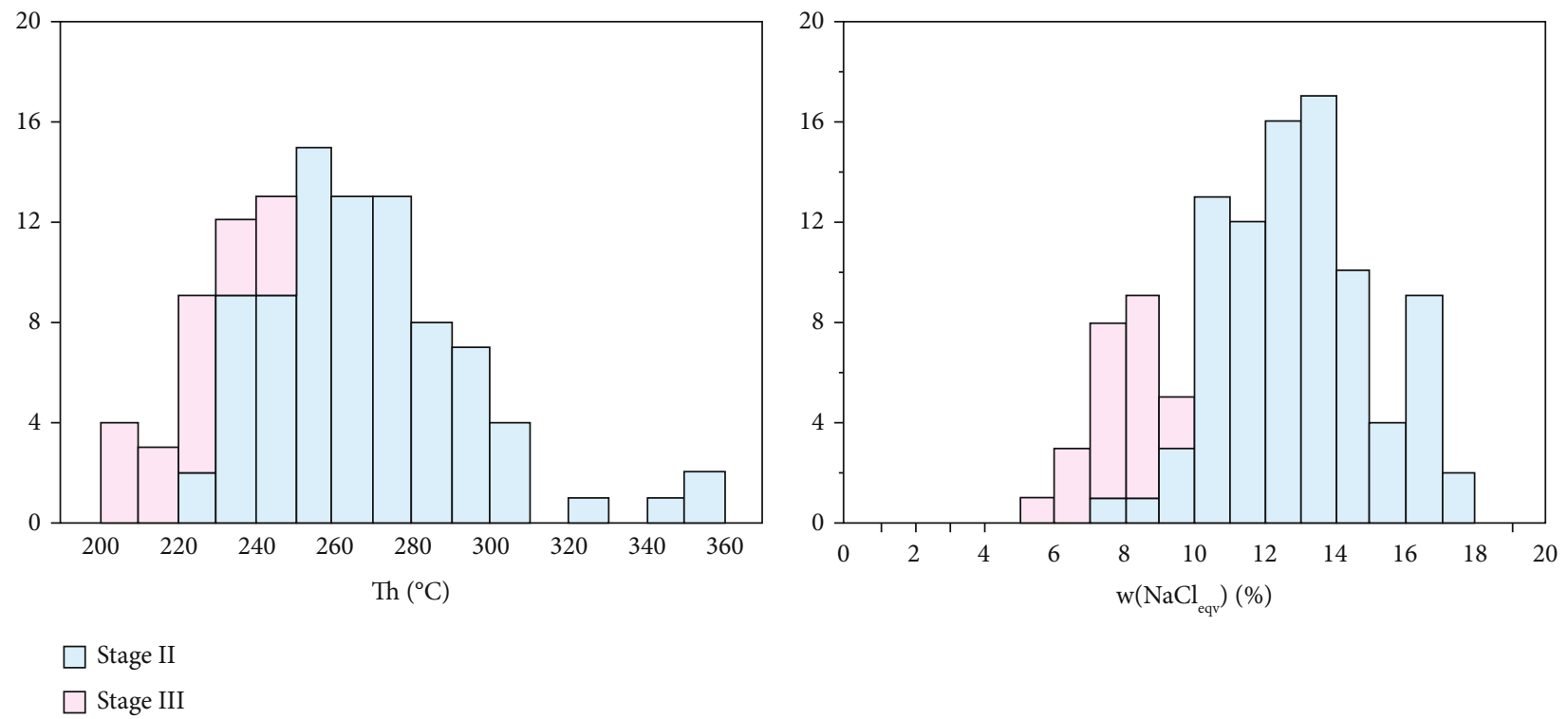

FIgURE 9: Histograms of homogenization temperatures and salinities of fluid inclusions in the Tieling Cu-Mo deposit. $T_{\mathrm{h}}$ : total homogenization temperature.

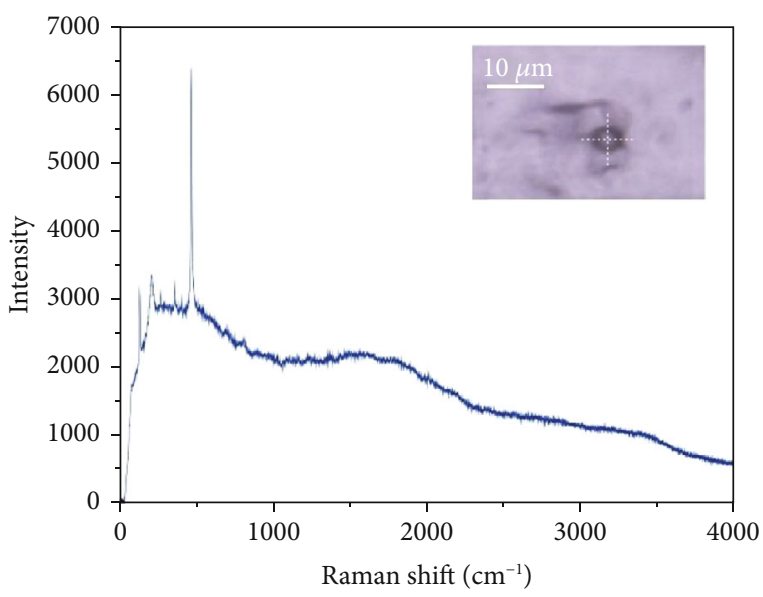

FIGURE 10: Laser Raman spectra of vapor-phase composition of WG-type fluid inclusions of the Tieling Cu-Mo deposit. primary gas component of WL-type fluid inclusions in quartz veins is mainly $\mathrm{H}_{2} \mathrm{O}$.

5.3. H-O-S Isotopes. The hydrogen and oxygen isotope data of the host minerals and water from fluid inclusions are

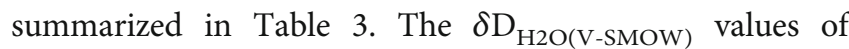
quartz in four samples from stage II range from $-79.5 \%$ to $-63.3 \%$, the $\delta^{18} \mathrm{O}_{\mathrm{O}(\mathrm{V} \text {-SMOw) }}$ values of quartz range from $8.8 \%$ o to $9.5 \%$, and the calculated $\delta^{18} \mathrm{O}_{\mathrm{H} 2 \mathrm{O}(\mathrm{V} \text {-SMOW) }}$ values of quartz range from $0.5 \%$ to $1.3 \%$. The $\delta \mathrm{D}_{\mathrm{H} 2 \mathrm{O}(\mathrm{V}-\mathrm{SMOW})}$ value of quartz in one sample from stage III is $-67.6 \%$,

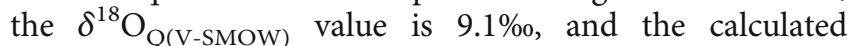
$\delta^{18} \mathrm{O}_{\mathrm{H} 2 \mathrm{O}(\mathrm{V}-\mathrm{SmOW})}$ value is $1.1 \%$.

Sulfur isotopic analysis on the Tieling deposit yielded pyrite and chalcopyrite. The sulfur isotopic compositions of seven pyrite samples and one chalcopyrite sample were analysed, and the corresponding measured $\delta^{34} \mathrm{~S}_{\mathrm{V} \text {-CDT }}$ values 
TABle 3: Hydrogen, oxygen, and sulfur isotopic compositions of the Tieling Cu-Mo deposit.

\begin{tabular}{|c|c|c|c|c|c|c|c|c|}
\hline Sample no. & Location & Stage & Mineral & $\delta{ }^{18} \mathrm{O}_{\mathrm{Q}}(\%)$ & $T_{\mathrm{c}}\left({ }^{\circ} \mathrm{C}\right)$ & $\delta \mathrm{D}_{\mathrm{H} 2 \mathrm{O}}(\% \mathrm{o})$ & $\delta^{18} \mathrm{O}_{\mathrm{H} 2 \mathrm{O}}(\% \mathrm{o})$ & $\delta^{34} \mathrm{~S}_{\mathrm{CDT}}(\%)$ \\
\hline $20 \mathrm{TL}-1-160$ & ZK9-1/160 m & Stage I & Pyrite & & & & & -0.8 \\
\hline 20TL-1-166 & ZK9-1/166 m & Stage I & Pyrite & & & & & -1.1 \\
\hline \multirow{2}{*}{ 20TL-3-78 } & \multirow{2}{*}{ ZK9-3/78 m } & \multirow{2}{*}{ Stage II } & Quartz & 8.9 & 282 & -63.9 & 1.3 & \\
\hline & & & Pyrite & & & & & 0.2 \\
\hline 20TL-3-80 & ZK9-3/80 m & Stage II & Quartz & 9.5 & 249 & -63.3 & 0.5 & \\
\hline \multirow{2}{*}{ 20TL-3-87 } & \multirow{2}{*}{ ZK9-3/87 m } & \multirow{2}{*}{ Stage II } & Quartz & 8.8 & 266 & -67.7 & 0.6 & \\
\hline & & & Pyrite & & & & & 1.3 \\
\hline 20TL-2-26 & ZK9-2/26 m & Stage II & Pyrite & & & & & 1.4 \\
\hline $20 \mathrm{TL}-2-167$ & ZK9-2/167 m & Stage II & Quartz & 9.3 & 267 & -79.5 & 1.1 & \\
\hline \multirow[t]{2}{*}{ 20TL-5-54 } & ZK9-5/54 m & Stage II & Pyrite & & & & & -1.6 \\
\hline & & & Quartz & 9.1 & 225 & -67.6 & -1.1 & \\
\hline \multirow[t]{2}{*}{$20 \mathrm{TL}-3-83$} & ZK9-3/83 m & Stage III & Pyrite & & & & & 1.4 \\
\hline & & & Chalcopyrite & & & & & -0.1 \\
\hline D443/2 & & Stage I & Pyrite & & & & & -1.5 \\
\hline D434/1 & & Stage I & Pyrrhotite & & & & & 0.5 \\
\hline D436/1 & & Stage I & Pyrrhotite & & & & & 0.1 \\
\hline
\end{tabular}

of minerals are listed in Table 3. The eight $\delta^{34} \mathrm{~S}_{\mathrm{V}-\mathrm{CDT}}$ values of the samples vary narrowly from $-1.6 \%$ to $1.4 \%$. The sulfur isotopic compositions of the disseminations, veins, and crumb ores are symmetrical and cluster near zero. The equilibrium temperature of symbiotic sulfides between the pyrite and chalcopyrite crystals was $275^{\circ} \mathrm{C}$.

\section{Discussion}

\subsection{Sources of Hydrothermal Fluid and Sulfur}

6.1.1. Sources of Hydrothermal Fluid. The fluid inclusions show that the ore-forming fluid has the characteristics of a relatively medium-low temperature, medium-high salinity, and medium-high density and represents a $\mathrm{NaCl}-\mathrm{H}_{2} \mathrm{O}$ system. The average corrected mineralization temperatures of stage II and stage III range from $268^{\circ} \mathrm{C}$ to $225^{\circ} \mathrm{C}$, which is consistent with the equilibrium temperature of sulfur isotopes $\left(275^{\circ} \mathrm{C}\right)$ and indicates that the corrected mineralization temperature is within the acceptable error range. The $\delta^{18} \mathrm{O}$ values of quartz in the Tieling deposit range from $8.8 \%$ o to $9.5 \%$, with an average value of $9.1 \%$ (Table 2 ), which is consistent with those of crustal remelting granite (10.0$12.0 \%$ [49]), indicating that the formation of hydrothermal quartz was associated with Carboniferous felsic intrusive rocks and was derived from magmatic fluids. The $\delta \mathrm{D}$ values of the fluids in the Tieling deposit mostly range from $-79.5 \%$ to $-63.3 \%$ o (Table 3 ) and approach those of magmatic water and meteoric water $[50,51]$. The $\mathrm{H}-\mathrm{O}$ isotope data of stages II and III plot between the primary magmatic water field and the meteoric water line (Figure 11), which is similar to other deposits in the same metallogenic belt [25, 52-57], indicating that the ore-forming fluids of the Tieling $\mathrm{Cu}-\mathrm{Mo}$ deposit were derived from Carboniferous magmatic hydrothermal fluids and then mixed with meteoric water.

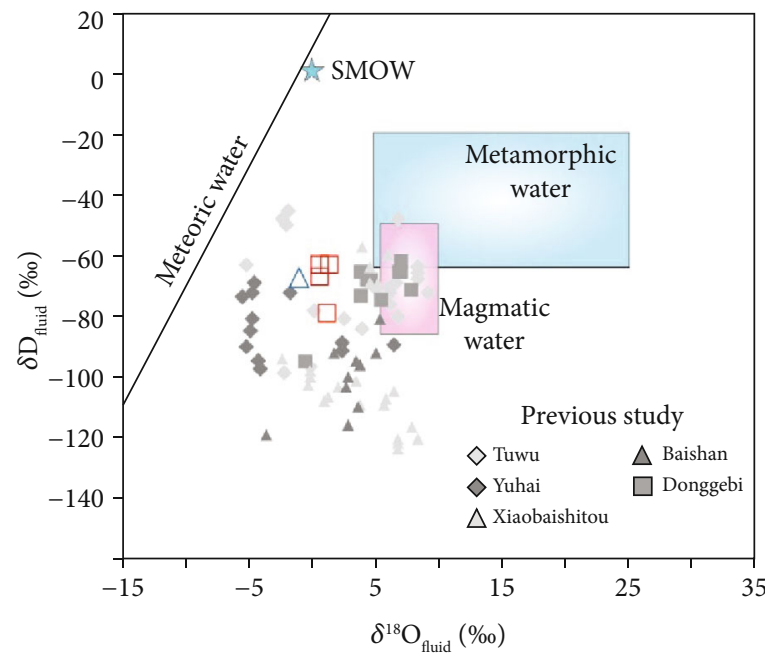

This study
$\square$ Stage II
$\triangle$ Stage III

FIgURE 11: $\delta \mathrm{D}_{\text {fluid }}$ vs. $\delta^{18} \mathrm{O}_{\text {fluid }}$ values from various stages in the Tieling $\mathrm{Cu}-\mathrm{Mo}$ deposit. Fields for magmatic and metamorphic water are from Taylor [50] and Sheppard [51]. The data of previous studies were referenced from Zhang et al. [54], Zhang et al. [25], Liu et al. [55], Wang et al. [56], and Li et al. [57].

6.1.2. Sources of Sulfur. The sulfide assemblage in the Tieling deposit is dominated by molybdenite and pyrite with minor chalcopyrite, and no sulfate minerals have been detected. Therefore, the hydrothermal system during the ore-forming process in the Tieling deposit was dominated by $\mathrm{H}_{2} \mathrm{~S}$. Molybdenite, pyrite, and chalcopyrite were formed under low- $f_{\mathrm{O} 2}$ and low-pH conditions [58]. According to Table 3 , the average $\delta^{34} \mathrm{~S}_{\mathrm{V}-\mathrm{CDT}}$ value for the seven pyrite samples collected from the Tieling deposit is $0.1 \%$, and 


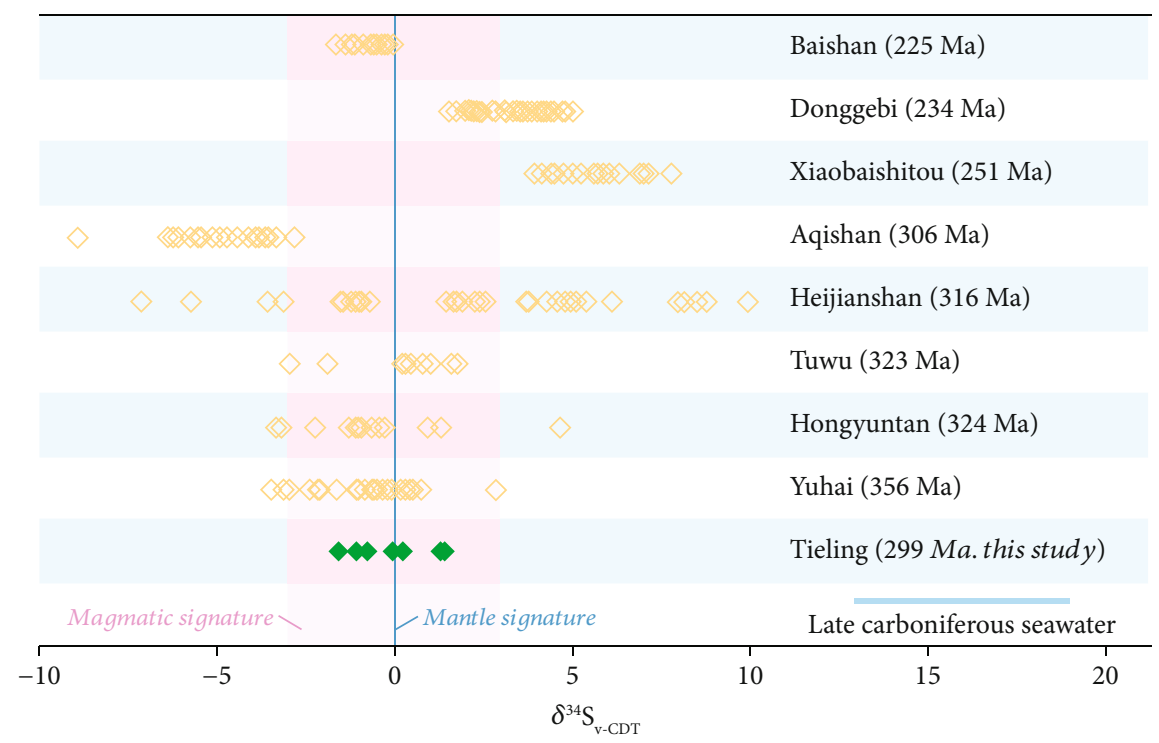

FiguRE 12: $\delta^{34} \mathrm{~S}_{\mathrm{V} \text {-CDT }}$ values of ore-forming fluids at Tieling and other major deposits in eastern Tianshan. Sulfur isotopic compositions of global seawater in the Late Carboniferous were modified after Holser [63]. Sulfur isotopic compositions of representative deposits were modified after Han et al. [14], Wang et al. [16], Zhang et al. [25], Sun et al. [39], Zhang et al. [54], Wang et al. [56], Dai et al. [61], and Zhao et al. [62].

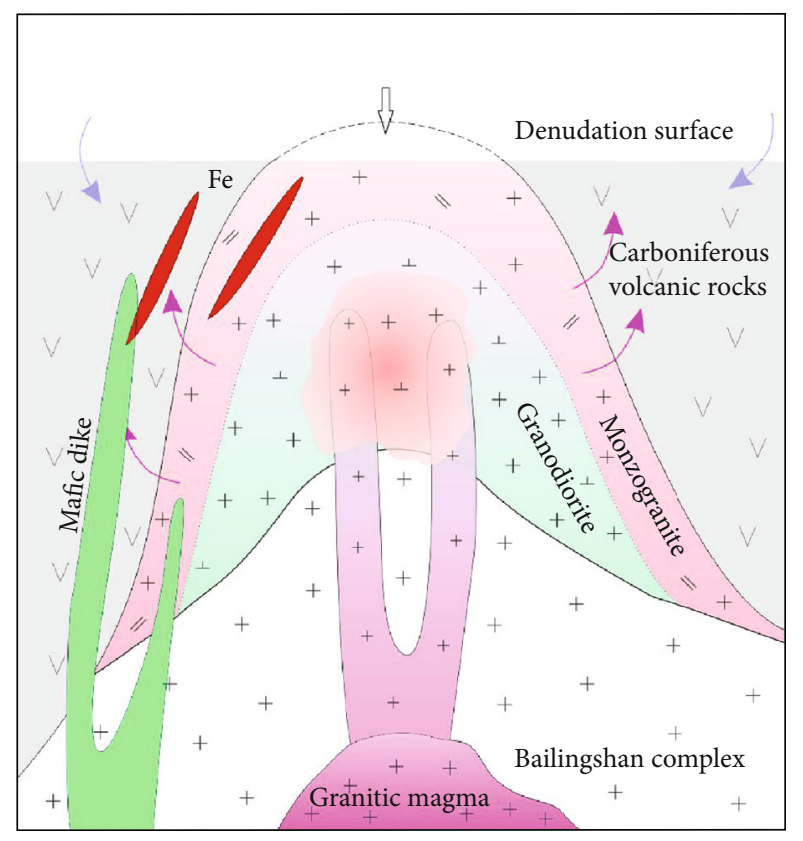

(a)

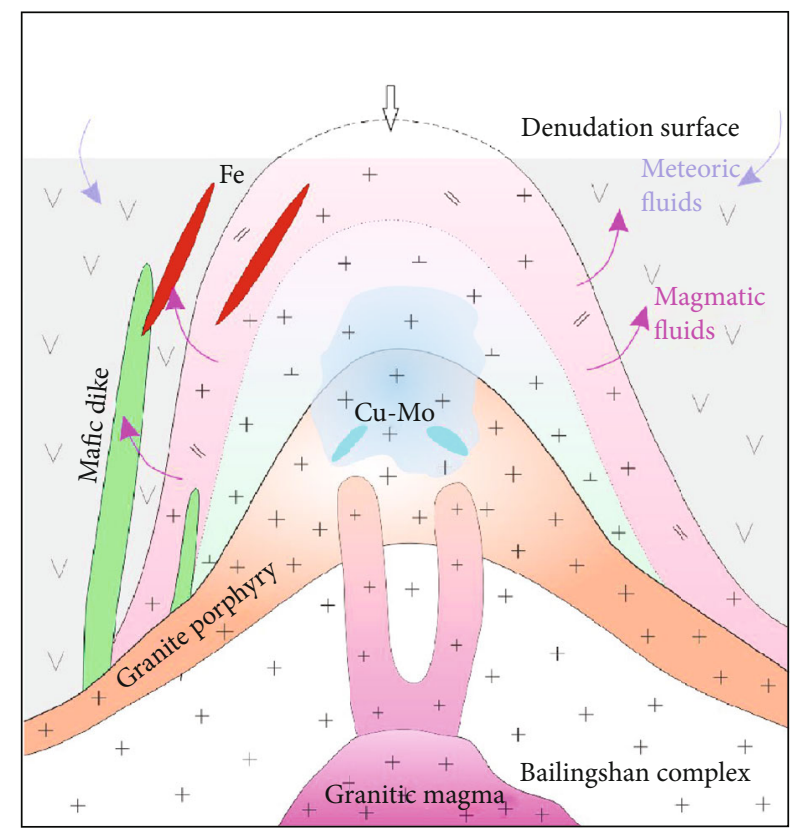

(b)

Figure 13: The metallogenic model of the Tieling copper-molybdenite deposit: (a) iron mineralization period in the early Late Carboniferous; (b) copper-molybdenum mineralization at the end of the Late Carboniferous.

the $\delta^{34} \mathrm{~S}_{\mathrm{V}-\mathrm{CDT}}$ value for one chalcopyrite sample is $-0.1 \%$. The basic sequence is consistent with the $\delta^{34} \mathrm{~S}$ enrichment condition of $\delta^{34} \mathrm{~S}_{\mathrm{Py}}>\delta^{34} \mathrm{~S}_{\mathrm{Ccp}}$ at isotopic equilibrium, indicating that the mineral $\mathrm{S}$ isotopes had reached equilibrium [59]. Therefore, the $S$ isotopic compositions of pyrite are close to the total $S$ isotopic compositions of the hydrothermal system and can be used to trace $S$ sources. The overall range of the $\delta^{34} \mathrm{~S}_{\mathrm{V} \text {-CDT }}$ values of sulfides in the Tieling deposit is narrow, indicating that the $S$ sources of sulfides deposited in the ore-forming hydrothermal fluids were undiversified. The $\delta^{34} \mathrm{~S}_{\mathrm{V}-\mathrm{CDT}}$ values are consistent with those of felsic magma [60] and other representative deposits related to magmatism $[14,16,25,39,54,56,61$, $62]$, indicating that the sulfur in the Tieling deposit was mainly derived from Late Carboniferous felsic magma (Figure 12). 
Table 4: Molybdenite Re-Os isochron ages of Mo deposits in northern Xinjiang, NW China.

\begin{tabular}{|c|c|c|c|c|c|c|c|}
\hline No. & Deposit & Type & Metal & Size & Method & Age (Ma) & Reference \\
\hline \multicolumn{8}{|c|}{ Altay } \\
\hline 1 & Asikaerte & Porphyry & $\mathrm{Be}, \mathrm{Mo}$ & Large & Molybdenite Re-Os & $\begin{array}{l}218.6 \pm 1.3 \\
228.7 \pm 7.1\end{array}$ & $\begin{array}{c}\text { Wang et al. [74] } \\
\text { Liu et al. [75] }\end{array}$ \\
\hline \multicolumn{8}{|c|}{ East Junggar } \\
\hline 2 & Suoerkuduke & Skarn & $\mathrm{Cu}, \mathrm{Mo}$ & Medium & Molybdenite Re-Os & $\begin{array}{c}317.1 \pm 7.6 \\
305 \pm 7\end{array}$ & $\begin{array}{c}\text { Liu and Liu [82] } \\
\text { Wan et al. [84] }\end{array}$ \\
\hline 3 & Xilekuduke & Porphyry & $\mathrm{Cu}, \mathrm{Mo}$ & Medium & Molybdenite Re-Os & $327.1 \pm 2.9$ & Long et al. [81] \\
\hline 4 & Yulekenhalasu & Porphyry & $\mathrm{Cu}, \mathrm{Mo}$ & Medium & Molybdenite Re-Os & $\begin{array}{l}331.5 \pm 4.8 \\
357.3 \pm 5.2 \\
376.9 \pm 2.2\end{array}$ & $\begin{array}{c}\text { Xiang et al. [85] } \\
\text { Xue et al. [86] }\end{array}$ \\
\hline 5 & Mengxi & Porphyry & $\mathrm{Cu}, \mathrm{Mo}$ & & Molybdenite Re-Os & $411.6 \pm 3.2$ & Qu et al. [87] \\
\hline \multicolumn{8}{|c|}{ West Junggar } \\
\hline 6 & Suyunhe & Porphyry & Mo & Giant & Molybdenite Re-Os & $294.4 \pm 1.7$ & Zhong et al. [78] \\
\hline 7 & Baogutu & Porphyry & $\mathrm{Cu}, \mathrm{Mo}$ & Large & Molybdenite Re-Os & $310 \pm 3.6$ & Song et al. [89] \\
\hline 8 & Hongyuan & Porphyry & Mo & & Molybdenite Re-Os & $\begin{array}{l}294.6 \pm 4.6 \\
314.3 \pm 1.9\end{array}$ & $\begin{array}{c}\operatorname{Li}[79] \\
\text { Yan et al. [80] }\end{array}$ \\
\hline \multicolumn{8}{|c|}{ West Tianshan } \\
\hline 9 & Dabate & Porphyry & $\mathrm{Cu}, \mathrm{Mo}$ & Small & Molybdenite Re-Os & $\begin{array}{c}300.3 \pm 2.1 \\
301 \pm 20\end{array}$ & $\begin{array}{c}\operatorname{Li}[92] \\
\text { Zhang et al. [91] }\end{array}$ \\
\hline 10 & Lailisigaoer & Porphyry & $\mathrm{Cu}, \mathrm{Mo}$ & Small & Molybdenite Re-Os & $\begin{array}{c}379.9 \pm 8.3 \\
359 \pm 8\end{array}$ & $\begin{array}{l}\text { Zhu et al. [90] } \\
\text { Li et al. [93] }\end{array}$ \\
\hline 11 & Kendenggaoer & Skarn & $\mathrm{Cu}, \mathrm{Mo}$ & Small & Molybdenite Re-Os & $313.9 \pm 2.5$ & Jia [88] \\
\hline \multicolumn{8}{|c|}{ East Tianshan } \\
\hline 12 & Tuwu-Yandong & Porphyry & $\mathrm{Cu}, \mathrm{Mo}$ & Large & Molybdenite Re-Os & $\begin{array}{c}323 \pm 2 \\
343 \pm 26\end{array}$ & $\begin{array}{l}\text { Rui et al. [65] } \\
\text { Zhang et al. [66] }\end{array}$ \\
\hline 13 & Donggebi & Porphyry & Mo & Giant & Molybdenite Re-Os & $\begin{array}{l}233.2 \pm 2.2 \\
231.1 \pm 1.5 \\
231.9 \pm 6.5 \\
234.3 \pm 1.6\end{array}$ & $\begin{array}{l}\text { Wu et al. [72] } \\
\text { Tu et al. [94] } \\
\text { Wu et al. [76] } \\
\text { Han et al. [14] }\end{array}$ \\
\hline 14 & Kumutage & Skarn & Mo & & Molybdenite Re-Os & $319.1 \pm 4.5$ & Zhang et al. [95] \\
\hline 15 & Yuhai & Porphyry & $\mathrm{Cu}, \mathrm{Mo}$ & Small & Molybdenite Re-Os & $355.7 \pm 2.4$ & Wang et al. [17] \\
\hline 16 & Sanchakou & Porphyry & $\mathrm{Cu}, \mathrm{Mo}$ & & Molybdenite Re-Os & $\begin{array}{l}416 \pm 6.4 \\
358 \pm 6.2\end{array}$ & $\begin{array}{c}\text { Lin et al. [64] } \\
\text { Liao and } \operatorname{Lv}[35]\end{array}$ \\
\hline 17 & Xiaobaishitou & Skarn & W, Mo & & Molybdenite Re-Os & $\begin{array}{l}239.7 \pm 3.6 \\
251.4 \pm 3.6 \\
251.1 \pm 1.6\end{array}$ & $\begin{array}{c}\text { Deng et al. [96] } \\
\text { Li et al. [57] }\end{array}$ \\
\hline 18 & Baishan & Porphyry & Mo & Giant & Molybdenite Re-Os & $\begin{array}{c}224.8 \pm 4.5 \\
227 \pm 4.3 \\
223.2 \pm 2.7\end{array}$ & $\begin{array}{c}\text { Zhang et al. [25] } \\
\text { Zhang et al. [73] } \\
\text { Tu et al. [15] }\end{array}$ \\
\hline 19 & Tieling & Porphyry & $\mathrm{Cu}-\mathrm{Mo}$ & & $\begin{array}{l}\text { Molybdenite Re-Os } \\
\text { Zircon U-Pb }\end{array}$ & $\begin{array}{l}299.0 \pm 7.7 \\
298.4 \pm 0.7\end{array}$ & $\begin{array}{l}\text { Unpublished } \\
\text { This study }\end{array}$ \\
\hline
\end{tabular}

6.2. Mineralization Age and Ore-Forming Process. In the early Paleozoic, porphyry $\mathrm{Cu}-\mathrm{Mo}-\mathrm{Au}$ deposits formed under the northward subduction of the Kanggur ocean basin, such as Sanchakou [64], Sanchakouxi [35], and Yudai [30]. During the Early Carboniferous, porphyry $\mathrm{Cu}-\mathrm{Mo}$ deposits in the northern Kanggur belt, such as Yuhai and Tuwu [65, 66], formed under the north-south bidirectional subduction of the Kanggur ocean basin. At the same time, a series of iron ores related to magmatism were formed in the southern
Kanggur belt, including those of the Bailingshan [67], Hongyuntan [39], and Duotoushan [68]. The ductile shear gold deposits were formed in Late Carboniferous [69], followed by abundant magmatic sulfide $\mathrm{Cu}-\mathrm{Ni}$ under the postcollisional extensional environment of the Early Permian [70, 71]. After approximately ca. $240 \mathrm{Ma}$, porphyry Mo deposits related to Triassic granite porphyry in a postcollisional environment were formed, including the Baishan and Donggebi deposits $[72,73]$. The zircon $\mathrm{U}-\mathrm{Pb}$ age from ore-bearing 


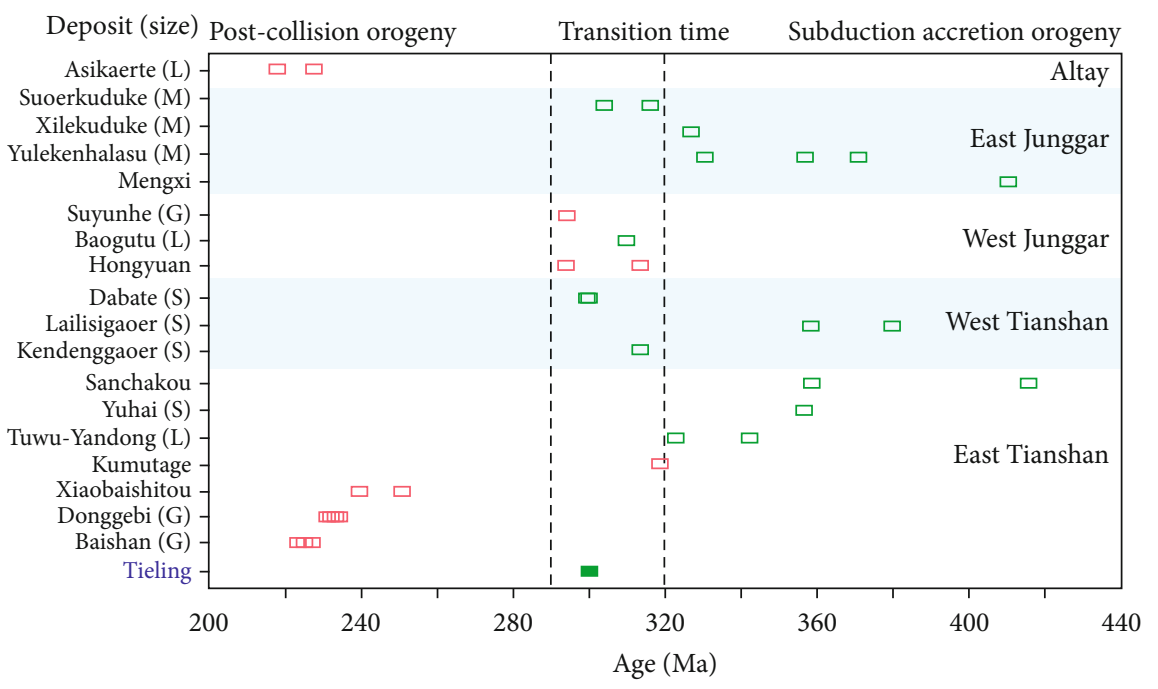

$$
\begin{aligned}
& \square \mathrm{Mo}, \mathrm{Be}-/ \mathrm{W}-\mathrm{Mo} \\
& \square \mathrm{Cu}-\mathrm{Mo}
\end{aligned}
$$

FIgure 14: Re-Os isotopic ages from the Mo deposits in northern Xinjiang, NW China.

granite porphyry yields a concordant age of $298.4 \pm 0.7 \mathrm{Ma}$, which is consistent with the molybdenite Re-Os isochron age $(299.0 \pm 7.7 \mathrm{Ma}$, in publishing). The chronology data of the two groups within error indicate that the Tieling $\mathrm{Cu}$ Mo deposit was decidedly formed during the Late Carboniferous.

Previous studies have shown that the iron orebodies taking tabular or lensoid shapes of the Tieling deposit were hosted in monzogranite and granodiorite along fractures [42]. The formation of the iron orebodies was considered related to the Bailingshan complex generated by the southward subduction of the Kanggur oceanic plate beneath the Yili-Central Tianshan block during 324 to $303 \mathrm{Ma}[42,67]$, and $\mathrm{Cu}-\mathrm{Mo}$ mineralization was supposed to have formed later than Fe mineralization. Therefore, the mineralization process of the Tieling deposit has been described as two distinct metallogenic periods, including $\mathrm{Fe}$ and $\mathrm{Cu}-\mathrm{Mo}$ periods. The iron orebodies related to volcanic rocks were formed first in the strata during the subduction stage of the early Late Carboniferous [42]. With the emplacement of the Bailingshan complex, iron orebodies were formed in monzogranite and granodiorite and partially in the contact zone with skarnization (Figure 13(a)). Magnetite was found in the later basic dikes [37]. At the end of the Late Carboniferous, the hydrothermal fluids released from the ore-bearing granite porphyry in the late crystallization stage were mixed with meteoric water, resulting in precipitation mineralization in favourable structural positions (Figure 13(b)).

6.3. Geological Significance. The Mo deposits mainly include (W-/Be-) Mo and Cu-Mo types in northern Xinjiang on the southwestern margin of the CAOB (Table 4). The (W-/Be-) Mo-type deposits were formed in the Triassic period resulting from postcollisional orogeny and mainly distributed in Altay [74, 75] and eastern Tianshan $[14,25,76,77]$. The (W-/Be-) Mo-type deposits distributed in West Junggar formed in the transition condition [78-80]. In addition, the Cu-Mo-type deposits formed before the Carboniferous were widely distributed in the northern region of Xinjiang [78-82]. All of them, including Suoerkuduke, Xilekuduke, Yulekenhalasu, and Mengxi in East Junggar [78, 79, 8285]; Baogutu in West Junggar [86]; Dabate, Lailisigaoer, and Kendenggaoer in West Tianshan [87-91]; and TuwuYandong, Yuhai, and Sanchakou in East Tianshan [17, 6466], were related to subduction-related accretion orogeny. Notably, Mo mineralization in the eastern Tianshan was concentrated in the Triassic and before the Early Carboniferous, with the (W-/Be-) Mo type related to collisional orogeny and the $\mathrm{Cu}-\mathrm{Mo}$ type related to subduction-related accretion orogeny (Figure 14). However, no significant $\mathrm{Cu}$ Mo deposits were found in the transitional time between the Triassic and Early Carboniferous in eastern Tianshan. Perhaps more attention should be given to prospecting because there are abundant contemporaneous $\mathrm{Cu}-\mathrm{Mo}$ deposits in West Junggar [86], East Junggar [79, 82], and West Tianshan $[88,89,91,92]$.

\section{Conclusions}

(1) The Tieling deposit is a porphyry system that exhibits three ore-forming stages, including quartz $+\mathrm{K}$-feldspar+pyrite \pm molybdenite \pm magnetite (stage I), quartz+molybdenite+pyrite+chalcopyrite (stage II), and quartz+pyrite \pm molybdenite \pm epidote (stage III)

(2) The ore-forming fluids of the Tieling Cu-Mo deposit are characterized by medium-low temperatures ( 224 to $355^{\circ} \mathrm{C}$ in stage II and 201 to $246^{\circ} \mathrm{C}$ in stage III), medium-high salinities $(7.2-17.2 \mathrm{wt} \% \mathrm{NaCl}$ equiv. of stage II and 5.6 to $9.6 \mathrm{wt} \% \mathrm{NaCl}$ equiv. of stage III), and a $\mathrm{H}_{2} \mathrm{O}-\mathrm{NaCl}$ composition 
(3) The H-O-S isotopes indicate that the ore-forming fluids were derived from a mixture of magmatic hydrothermal water and meteoric water and the ore-forming materials were derived from Late Carboniferous felsic magma

(4) The zircon $\mathrm{U}-\mathrm{Pb}$ of ore-bearing granite porphyry yields a concordant age of $298.4 \pm 0.7 \mathrm{Ma}$, indicating that the Tieling $\mathrm{Cu}-\mathrm{Mo}$ deposit was a rare metallogenic event in the Late Carboniferous of the eastern Tianshan, which should be given more attention for prospecting

\section{Data Availability}

The data used to support the findings of this study are available from the corresponding authors upon request.

\section{Conflicts of Interest}

The authors declare that there is no conflict of interest regarding the publication of this paper.

\section{Acknowledgments}

We thank Yonggang Feng and Wei Du from the Chang'an University for their help during fluid inclusion analyses, and we thank Senior Engineer Mu Liu from the Beijing Research Institute of Uranium Geology for her help during $\mathrm{H}-\mathrm{O}-\mathrm{S}$ isotope analyses. We also thank Wanzhi Yang, Ganggang Yang, Qiong Han, and Liuyuan Jin of the Xinjiang Geological Survey Academy for their support and assistance during the fieldwork. This work was financially supported by the Project of the China Geological Survey (Grant no. DD20190379), the Project of the Xinjiang Natural Science Youth Fund (Grant no. 2020D01B51), the National Key R\&D Project of China (Grant No. 2018YFC0604001-04), and the Natural Science Basic Research Program of Shanxi (Grant no. 2020JQ-974).

\section{References}

[1] J. P. Richards, "Postsubduction porphyry $\mathrm{Cu}-\mathrm{Au}$ and epithermal $\mathrm{Au}$ deposits: products of remelting of subductionmodified lithosphere," Geology, vol. 37, no. 3, pp. 247-250, 2009.

[2] F. Pirajno, R. E. Ernst, A. S. Borisenko, G. Fedoseev, and E. A. Naumov, "Intraplate magmatism in Central Asia and China and associated metallogeny," Ore Geology Reviews, vol. 35, no. 2, pp. 114-136, 2009.

[3] R. H. Sillitoe, "A plate tectonic model for the origin of porphyry copper deposits," Economic Geology, vol. 67, no. 2, pp. 184-197, 1972.

[4] C. R. Stern, M. A. Skewes, and A. Arevalo, "Magmatic evolution of the giant El Teniente $\mathrm{Cu}-\mathrm{Mo}$ deposit, Central Chile," Journal of Petrology, vol. 52, no. 7-8, pp. 1591-1617, 2011.

[5] J. P. Richards, "High Sr/Y arc magmas and porphyry $\mathrm{Cu} \pm \mathrm{Mo}$ \pm Au deposits: just add water," Economic Geology, vol. 106, no. 7, pp. 1075-1081, 2011.

[6] Z. Q. Hou, Z. M. Yang, X. M. Qu et al., “The Miocene Gangdese porphyry copper belt generated during post-collisional extension in the Tibetan orogen," Ore Geology Reviews, vol. 36, no. 1-3, pp. 25-51, 2009.

[7] Z. Q. Hou, H. R. Zhang, X. F. Pan, and Z. M. Yang, "Porphyry $\mathrm{Cu}$ (-Mo-Au) deposits related to melting of thickened mafic lower crust: examples from the eastern Tethyan metallogenic domain," Ore Geology Reviews, vol. 39, no. 1-2, pp. 21-45, 2011.

[8] J. P. Richards, "Magmatic to hydrothermal metal fluxes in convergent and collided margins," Ore Geology Reviews, vol. 40, no. 1, pp. 1-26, 2011.

[9] Y. J. Chen, "The development of continental collision metallogeny and its application," Acta Petrologica Sinica, vol. 29, no. 1, pp. 1-17, 2013.

[10] Y. J. Chen, P. Wang, N. Li, Y. F. Yang, and F. Pirajno, "The collision-type porphyry Mo deposits in Dabie Shan, China," Ore Geology Reviews, vol. 81, no. 2, pp. 405-430, 2017.

[11] P. Wang, Y. J. Chen, B. Fu, Y. F. Yang, M. Mi, and Z. L. Li, "Fluid inclusion and $\mathrm{H}-\mathrm{O}-\mathrm{C}$ isotope geochemistry of the Yaochong porphyry Mo deposit in Dabie Shan, China: a case study of porphyry systems in continental collision orogens," International Journal of Earth Sciences, vol. 103, no. 3, pp. 777-797, 2014.

[12] M. Mi, Y. J. Chen, Y. F. Yang et al., "Geochronology and geochemistry of the giant Qian'echong Mo deposit, Dabie Shan, eastern China: implications for ore genesis and tectonic setting," Gondwana Research, vol. 27, no. 3, pp. 1217-1235, 2015.

[13] Y. F. Yang, Y. J. Chen, F. Pirajno, N. Li, and N. Li, "Evolution of ore fluids in the Donggou giant porphyry Mo system, East Qinling, China, a new type of porphyry Mo deposit: evidence from fluid inclusion and $\mathrm{H}-\mathrm{O}$ isotope systematics," Ore Geology Reviews, vol. 65, no. 1, pp. 148-164, 2015.

[14] C. M. Han, W. J. Xiao, G. C. Zhao, M. Sun, W. J. Qu, and A. D. $\mathrm{Du}$, "Re-Os geochronology on molybdenites from the Donggebi Mo deposit in the eastern Tianshan of the Central Asia Orogenic Belt and its geological significance," Resource Geology, vol. 64, no. 2, pp. 136-148, 2014.

[15] Q. J. Tu, Y. S. Wang, and L. H. Dong, "Re-Os dating of molybdenite from the Baishan molybdenum deposit in the eastern Tianshan area of Xinjiang and its geological significance," Xinjiang Geology, vol. 32, no. 3, pp. 322-327, 2014.

[16] Y. H. Wang, C. J. Xue, J. J. Liu et al., "Early Carboniferous adakitic rocks in the area of the Tuwu deposit, eastern Tianshan, NW China: slab melting and implications for porphyry copper mineralization," Journal of Asian Earth Sciences, vol. 103, pp. 332-349, 2015.

[17] Y. H. Wang, F. F. Zhang, and J. J. Liu, "The genesis of the ores and intrusions at the Yuhai $\mathrm{Cu}-\mathrm{Mo}$ deposit in eastern Tianshan, NW China: constraints from geology, geochronology, geochemistry, and Hf isotope systematics," Ore Geology Reviews, vol. 77, pp. 312-331, 2016.

[18] W. F. Zhang, H. Y. Chen, L. H. Peng et al., "Discriminating hydrothermal fluid sources using tourmaline boron isotopes: example from Bailingshan Fe deposit in the eastern Tianshan, NW China," Ore Geology Reviews, vol. 98, pp. 28-37, 2018.

[19] A. M. C. Sengör, B. A. Natal'In, and V. S. Burtman, "Evolution of the Altaid tectonic collage and Palaeozoic crustal growth in Eurasia," Nature, vol. 364, no. 6435, pp. 299-307, 1993.

[20] B. F. Windley, D. Alexeiev, W. J. Xiao, A. Kröner, and G. Badarch, "Tectonic models for accretion of the Central Asian Orogenic Belt," Journal of the Geological Society, London, vol. 164, no. 1, pp. 31-47, 2007. 
[21] Y. S. Wu, K. F. Zhou, N. Li, and Y. J. Chen, "Zircon U-Pb dating and $\mathrm{Sr}-\mathrm{Nd}-\mathrm{Pb}-\mathrm{Hf}$ isotopes of the ore-associated porphyry at the giant Donggebi Mo deposit, Eastern Tianshan, NW China," Ore Geology Reviews, vol. 81, pp. 794-807, 2017.

[22] W. J. Xiao, D. F. Song, B. F. Windley et al., "Accretionary processes and metallogenesis of the Central Asian Orogenic Belt: advances and perspectives," Science China Earth Sciences, vol. 63, no. 3, pp. 329-361, 2020.

[23] Q. G. Mao, J. B. Wang, M. J. Yu et al., "Re-Os and U-Pb geochronology for the Xiaorequanzi VMS deposit in the eastern Tianshan, NW China: constraints on the timing of mineralization and stratigraphy," Ore Geology Reviews, vol. 122, article 103473, 2020.

[24] X. H. Cheng, F. Q. Yang, R. Zhang, Q. F. Xu, and N. Li, "Metallogenesis and fluid evolution of the Huangtupo $\mathrm{Cu}-\mathrm{Zn}$ deposit, East Tianshan, Xinjiang, NW China: constraints from ore geology, fluid inclusion geochemistry, $\mathrm{H}-\mathrm{O}-\mathrm{S}$ isotopes, and U-Pb zircon, Re-Os chalcopyrite geochronology," Ore Geology Reviews, vol. 121, article 103469, 2020.

[25] L. C. Zhang, W. J. Xiao, K. Z. Qin, W. J. Qu, and A. D. Du, "Re-Os isotopic dating of molybdenite and pyrite in the Baishan Mo-Re deposit, eastern Tianshan, NW China, and its geological significance," Mineralium Deposita, vol. 39, no. 8, pp. 960-969, 2005.

[26] Y. J. Mao, K. Z. Qin, D. M. Tang, H. Y. Feng, and S. C. Xue, "Crustal contamination and sulfide immiscibility history of the Permian Huangshannan magmatic Ni-Cu sulfide deposit, East Tianshan, NW China," Journal of Asian Earth Sciences, vol. 129, pp. 22-37, 2016.

[27] S. M. Wang, C. Z. Wu, M. N. Muhtar, R. X. Lei, and M. J. Brzozowski, "Mobilization of ore-forming metals during postmagmatic hydrothermal overprinting of the Huangshandong $\mathrm{Ni}-\mathrm{Cu}$ sulfide deposit, Eastern Tianshan, NW China," Ore Geology Reviews, vol. 137, article 104315, 2021.

[28] M. N. Muhtar, C. Z. Wu, M. J. Brzozowski et al., "Sericite ${ }^{40} \mathrm{Ar} /{ }^{39} \mathrm{Ar}$ dating and $\mathrm{S}-\mathrm{Pb}$ isotope composition of the Kanggur gold deposit: Implications for metallogenesis of late Paleozoic gold deposits in the Tianshan, central Asian Orogenic Belt," Ore Geology Reviews, vol. 131, article 104056, 2021.

[29] J. S. Han, H. Y. Chen, H. J. Jiang, L. D. Zhao, W. F. Zhang, and C. K. Lai, "Genesis of the Paleozoic Aqishan-Yamansu arcbasin system and $\mathrm{Fe}(-\mathrm{Cu})$ mineralization in the eastern Tianshan, NW China," Ore Geology Reviews, vol. 105, pp. 55-70, 2019.

[30] Y. Sun, J. B. Wang, Y. C. Li et al., "Recognition of Late Ordovician Yudai porphyry $\mathrm{Cu}(\mathrm{Au}, \mathrm{Mo})$ mineralization in the Kalatag district, eastern Tianshan terrane, NW China: constraints from geology, geochronology, and petrology," Ore Geology Reviews, vol. 100, pp. 220-236, 2018.

[31] M. Sun, Y. H. Wang, F. F. Zhang et al., "Petrogenesis of Late Carboniferous intrusions in the Linglong area of Eastern Tianshan, NW China, and tectonic implications: geochronological, geochemical, and zircon Hf-O isotopic constraints," Ore Geology Reviews, vol. 120, article 103462, 2020.

[32] H. Wu, H. Q. Li, F. W. Chen et al., "Zircon SHRIMP U-Pb dating of plaglogranite porphyry in the Chihu molybdenumcopper district, Hami, east Tianshan," Geological Bulletin of China, vol. 25, pp. 549-552, 2006.

[33] Y. H. Wang, F. F. Zhang, J. J. Liu, and C. Y. Que, "Genesis of the Fuxing porphyry $\mathrm{Cu}$ deposit in Eastern Tianshan, China: evidence from fluid inclusions and $\mathrm{C}-\mathrm{H}-\mathrm{O}-\mathrm{S}-\mathrm{Pb}$ isotope systematics," Ore Geology Reviews, vol. 79, pp. 46-61, 2016.
[34] B. Xiao, H. Y. Chen, P. Hollings et al., "Magmatic evolution of the Tuwu-Yandong porphyry Cu belt, NW China: constraints from geochronology, geochemistry and Sr-Nd-Hf isotopes," Gondwana Research, vol. 43, pp. 74-91, 2017.

[35] K. L. Liao and C. L. Lv, “The geological significance of molybdenite $\mathrm{Re}-\mathrm{Os}$ isotope dating result of Sanchakouxi $\mathrm{Cu}$ deposit in east Tianshan, Xinjiang," Mineral Resources and Geology, vol. 34, no. 3, pp. 471-476, 2020.

[36] C. M. Han, W. J. Xiao, B. X. Su et al., "Geology, Re-Os and U$\mathrm{Pb}$ geochronology and sulfur isotope of the the Donggebi porphyry Mo deposit, Xinjiang, NW China, Central Asian Orogenic Belt," Journal of Asian Earth Sciences, vol. 165, pp. 270-284, 2018.

[37] X. P. Long, B. Wu, M. Sun, C. Yuan, W. J. Xiao, and R. Zuo, "Geochronology and geochemistry of Late Carboniferous dykes in the Aqishan-Yamansu belt, eastern Tianshan: evidence for a post-collisional slab breakoff," Geoscience Frontiers, vol. 11, no. 1, pp. 347-362, 2020.

[38] W. F. Zhang, H. Y. Chen, L. H. Peng et al., "Ore genesis of the Duotoushan $\mathrm{Fe}-\mathrm{Cu}$ deposit, eastern Tianshan, NW China: constraints from ore geology, mineral geochemistry, fluid inclusion and stable isotopes," Ore Geology Reviews, vol. 100, pp. 401-421, 2018.

[39] Z. Y. Sun, L. L. Long, Y. W. Wang, Z. H. Luo, Q. T. Hu, and M. L. Wang, "Geology, chronology, fluid inclusions, and $\mathrm{H}-$ $\mathrm{O}-\mathrm{S}$ isotopic compositions of the Hongyuntan magnetite deposit, eastern Tianshan, NW China," Journal of Asian Earth Sciences, vol. 172, pp. 328-345, 2019.

[40] N. Li, F. Q. Yang, Z. X. Zhang, and C. D. Yang, "Geochemistry and chronology of the biotite granite in the Xiaobaishitou W(Mo) deposit, eastern Tianshan, China: petrogenesis and tectonic implications," Ore Geology Reviews, vol. 107, pp. 9991019, 2019.

[41] W. F. Zhang, H. Y. Chen, J. S. Han et al., "Geochronology and geochemistry of igneous rocks in the Bailingshan area: implications for the tectonic setting of late Paleozoic magmatism and iron skarn mineralization in the eastern Tianshan, NW China," Gondwana Research, vol. 38, pp. 40-59, 2016.

[42] S. H. Fan, S. E. Chen, Y. B. Zhang, L. Zhang, L. Liu, and L. C. Yang, "The characteristics and geneses of iron deposits in the Bailingshan area, eastern Tianshan, Xinjiang, NW China," Geological Journal, vol. 53, pp. 319-328, 2018.

[43] K. R. Ludwig, User's Manual for Isoplot/Ex. Version 3.00: a Geochronological Toolkit for Microsoft Excel, Berkeley Geochronology Center Special Publication, Berkeley, 2003.

[44] R. J. Bodnar, "Revised equation and table for determining the freezing point depression of $\mathrm{H}_{2} \mathrm{O}-\mathrm{NaCl}$ solutions," Geochimica et Cosmochimica Acta, vol. 57, no. 3, pp. 683-684, 1993.

[45] B. Liu and K. Shen, Thermodynamics of fluid inclusions, Geological Publishing House, Beijing, 1999.

[46] R. N. Clayton, J. R. O'Neil, and T. K. Mayeda, "Oxygen isotope exchange between quartz and water," Journal of Geophysical Reseach, vol. 77, no. 17, pp. 3057-3067, 1972.

[47] Y. Kajiwara and H. R. Krouse, "Sulfur isotope partitioning in metallic sulfide systems," Canadian Journal of Earth Sciences, vol. 8, no. 11, pp. 1397-1408, 1971.

[48] R. H. Sillitoe, "Porphyry copper systems," Economic Geology, vol. 105, no. 1, pp. 3-41, 2010.

[49] Y. J. Chen, C. Li, J. Zhang, Z. Li, and H. H. Wang, "Sr and O isotopic characteristics of porphyries in the Qinling molybdenum deposit belt and their implication to genetic mechanism 
and type," Science in China Series D-Earth Sciences, vol. 43, no. S1, pp. 82-94, 2000.

[50] H. P. Taylor, "Oxygen and hydrogen isotope relationships in hydrothermal mineral deposits," Geochemistry of Hydrothermal Ore Deposits, H. L. Barnes, Ed., pp. 236-277, Wiley, New York, NY, USA, 1997.

[51] S. M. F. Sheppard, "Characterization and isotopic variations in natural waters," Reviews in Mineralogy, vol. 16, pp. 165-183, 1986.

[52] Y. H. Wang, C. J. Xue, F. F. Zhang, J. J. Liu, J. B. Gao, and T. J. Qi, "SHRIMP zircon U-Pb geochronology, geochemistry and $\mathrm{H}-\mathrm{O}-\mathrm{Si}-\mathrm{S}-\mathrm{Pb}$ isotope systematics of the Kanggur gold deposit in Eastern Tianshan, NW China: implication for ore genesis," Ore Geology Reviews, vol. 68, pp. 1-13, 2015.

[53] L. D. Zhao, J. S. Han, W. J. Lu, P. Liang, and F. Jourdan, "The Middle Permian Hongshanliang Manto-type copper deposit in the East Tianshan: constraints from geology, geochronology, fluid inclusions and H-O-S isotopes," Ore Geology Reviews, vol. 124, article 103601, 2020.

[54] F. F. Zhang, Y. H. Wang, C. J. Xue, J. J. Liu, and W. Zhang, "Fluid inclusion and isotope evidence for magmatichydrothermal fluid evolution in the Tuwu porphyry copper deposit, Xinjiang, NW China," Ore Geology Reviews, vol. 113, article 103078, 2019.

[55] S. J. Liu, J. J. Yu, T. Z. Wang et al., "Fluid inclusions and stable isotope study of Yuhai copper-(molybdenum) deposit in eastern Tianshan Mountains, Xinjiang," Mineral Deposits, vol. 37, pp. 371-386, 2018.

[56] Y. H. Wang, F. F. Zhang, J. J. Liu, C. J. Xue, B. C. Li, and X. C. Xian, "Ore genesis and hydrothermal evolution of the Donggebi porphyry Mo deposit, Xinjiang, northwest China: evidence from isotopes $(\mathrm{C}, \mathrm{H}, \mathrm{O}, \mathrm{S}, \mathrm{Pb})$, fluid inclusions, and molybdenite Re-Os dating," Economic Geology, vol. 113, no. 2, pp. 463-488, 2018.

[57] N. Li, F. Q. Yang, Z. X. Zhang, and C. Li, "Dating the Xiaobaishitou skarn $\mathrm{W}$-(Mo) deposit, eastern Tianshan, NW China: constraints from zircon U-Pb, muscovite ${ }^{40} \mathrm{Ar}-{ }^{39} \mathrm{Ar}$, and molybdenite Re-Os system," Ore Geology Reviews, vol. 124, article 103637, 2020.

[58] H. Ohmoto, "Systematics of sulfur and carbon isotopes in hydrothermal ore deposits," Economic Geology, vol. 67, no. 5, pp. 551-578, 1972.

[59] H. Ohmoto, "Stable isotope geochemistry of ore deposits," Stable Isotopes in High Temperature Geological Processes. Review in Mineralogy, J. W. Valley, H. P. Taylor, and J. R. O'Neil, Eds., vol. 16, pp. 460-491, 1986.

[60] H. Ohmoto and R. O. Rye, "Isotopes of sulfur and carbon," in Geochemistry of Hydrothermal Ore Deposit, H. L. Barnes, Ed., pp. 509-567, Wiley, New York, 1979.

[61] J. F. Dai, C. J. Xue, G. X. Chi et al., "Genesis of the Aqishan skarn $\mathrm{Zn}-\mathrm{Pb}$ deposit in the eastern Tianshan, NW China: constraints from geology, geochronology and $\mathrm{Hf}-\mathrm{S}-\mathrm{Pb}$ isotopic geochemistry," Ore Geology Reviews, vol. 123, no. 103608, article 103608, 2020.

[62] L. D. Zhao, H. Y. Chen, L. Zhang, W. F. Zhang, J. T. Yang, and X. L. Yan, "The Late Paleozoic magmatic evolution of the Aqishan-Yamansu belt, eastern Tianshan: constraints from geochronology, geochemistry and $\mathrm{Sr}-\mathrm{Nd}-\mathrm{Pb}-\mathrm{Hf}$ isotopes of igneous rocks," Journal of Asian Earth Sciences, vol. 153, pp. 170-192, 2018.
[63] W. T. Holser, "Catastrophic chemical events in history of the ocean," Nature, vol. 267, pp. 402-408, 1977.

[64] T. Lin, Y. F. Deng, W. J. Qu, T. F. Zhou, F. Yuan, and G. Deng, "The genesis, petrology, chronology and geochemical evidence of the Sanchakou copper deposit in the east Tianshan area, Xinjiang," Journal of Mineral Petrology, vol. 37, no. 4, pp. 47-61, 2017.

[65] Z. Y. Rui, R. J. Goldfarb, Y. M. Qiu et al., "Paleozoic-early Mesozoic gold deposits of the Xinjiang autonomous region, northwestern China," Mineralium Deposita, vol. 37, no. 3, pp. 393-418, 2002.

[66] L. C. Zhang, K. Z. Qin, and W. J. Xiao, "Multiple mineralization events in the eastern Tianshan district, NW China: isotopic geochronology and geological significance," Journal of Asian Earth Sciences, vol. 32, no. 2-4, pp. 236-246, 2008.

[67] L. D. Zhao, H. Y. Chen, P. Hollings, and J. S. Han, "Late Paleozoic magmatism and metallogenesis in the AqishanYamansu belt, eastern Tianshan: constraints from the Bailingshan intrusive complex," Gondwana Research, vol. 65, pp. 68-85, 2019.

[68] W. F. Zhang, H. Y. Chen, H. J. Jiang et al., "Geochronology, geochemistry and petrogenesis of granitoids in the duotoushan $\mathrm{Fe}-\mathrm{Cu}$ deposit, Eastern Tianshan, Xinjiang: implications on tectonic setting of late paleozoic magmatism," Geotectonica et Metallogenia, vol. 41, pp. 1171-1191, 2017.

[69] M. N. Muhtar, C. Z. Wu, M. J. Brzozowski et al., "Geochronology, geochemistry, and $\mathrm{Sr}-\mathrm{Nd}-\mathrm{Pb}-\mathrm{Hf}-\mathrm{S}$ isotopes of the wall rocks of the Kanggur gold polymetallic deposit, Chinese North Tianshan: implications for petrogenesis and sources of oreforming materials," Ore Geology Reviews, vol. 125, article 103688, 2020.

[70] C. Z. Wu, S. W. Xie, L. X. Gu et al., "Shear zone-controlled post-magmatic ore formation in the Huangshandong $\mathrm{Ni}-\mathrm{Cu}$ sulfide deposit, NW China," Ore Geology Reviews, vol. 100, pp. 545-560, 2018.

[71] P. Li, T. Liang, Y. G. Feng et al., "The metallogeny of the Lubei $\mathrm{Ni}-\mathrm{Cu}-\mathrm{Co}$ sulfide deposit in eastern Tianshan, NW China: insights from petrology and Sr-Nd-Hf isotopes," Frontiers in Earth Science, vol. 9, 2021.

[72] Y. S. Wu, N. Xiang, H. S. Tang, K. F. Zhou, and Y. F. Yang, "Molybdenite Re-Os isotope age of the Donggebi Mo deposit and the Indosinian metallogenic event in eastern Tianshan," Acta Petrologica Sinica, vol. 29, pp. 121-130, 2013.

[73] D. Y. Zhang, T. F. Zhou, F. Yuan, Y. Fan, S. Liu, and W. J. Qu, "A genetic analysis of Baishan molybdenum deposit in east Tianshan area, Xinjiang," Mineral Deposits, vol. 28, no. 5, pp. 663-672, 2009.

[74] C. L. Wang, K. Z. Qin, D. M. Tang et al., "Geochronology and $\mathrm{Hf}$ isotope of zircon for the Arskartor Be-Nb-Mo deposit in Altay and its geological implications," Acta Petrologica Sinica, vol. 31, pp. 2337-2352, 2015.

[75] W. Z. Liu, H. Zhang, H. F. Tang, Y. Tang, and Z. H. Lv, "Molybdenite Re-Os dating of the Asikaerte Be-Mo deposit in Xinjiang, China and its genetic implications," Geochimica, vol. 44, pp. 145-154, 2015.

[76] Y. H. Wu, X. L. Xiong, T. P. Zhao, Z. M. Zhu, and L. Li, "Zircon $\mathrm{U}-\mathrm{Pb}$ age of the ore-bearing granite and molybdenite $\mathrm{Re}-\mathrm{Os}$ isotopic age of the Donggebi Mo deposit, Xinjiang and their geological significance," Geotectonica et Metallogenia, vol. 37, no. 4, pp. 743-753, 2013. 
[77] Y. S. Wu, Y. J. Chen, and K. F. Zhou, "Mo deposits in northwest China: geology, geochemistry, geochronology and tectonic setting," Ore Geology Reviews, vol. 81, pp. 641-671, 2017.

[78] S. H. Zhong, P. Shen, H. D. Pan, G. P. Zheng, Y. H. Yan, and J. Li, "The ore-forming fluid and geochronology of the Suyunhe Mo deposit, west Junggar, Xinjiang," Acta Petrologica Sinica, vol. 31, pp. 449-464, 2015.

[79] W. D. Li, The geological characteristics and genesis of the Hongyuan porphyry Mo $(\mathrm{Cu})$ deposit from west Junggar, [Ph.D. thesis], China University of Geosciences, Beijing, 2013.

[80] H. Y. Yan, P. Shen, H. D. Pan, J. N. Wang, S. H. Zhong, and X. G. Liu, "Research on the fluid inclusion and Re-Os dating of Hongyuan $(\mathrm{Cu})$ Mo deposit and Tuketuke Mo-Cu deposit, west Junggar, Xinjiang," Chinese Journal of Geology, vol. 49, pp. 287-304, 2014.

[81] L. L. Long, Y. W. Wang, A. D. Du et al., "Molybdenite Re-Os age of Xilekuduke $\mathrm{Cu}-\mathrm{Mo}$ deposit in Xinjiang and its geological significance," Mineral Deposits, vol. 30, pp. 635-644, 2011.

[82] X. J. Liu and W. Liu, "Re-Os dating of the Suoerkuduke Cu (Mo) deposit, Fuyun County, Xinjiang, and its geodynamic implications," Journal of Earth Science, vol. 24, no. 2, pp. 188-202, 2013.

[83] F. Q. Yang, F. M. Chai, Z. X. Zhang, X. X. Geng, and Q. Li, "Zircon U-Pb geochronology, geochemistry, and Sr-Nd-Hf isotopes of granitoids in the Yulekenhalasu copper ore district, northern Junggar, China: petrogenesis and tectonic implications," Lithos, vol. 190-191, pp. 85-103, 2014.

[84] B. Wan, W. J. Xiao, C. M. Han et al., "Re-Os molybdenite age of the $\mathrm{Cu}$-Mo skarn ore deposit at Suoerkuduke in East Junggar, NW China and its geological significance," Ore Geology Reviews, vol. 56, pp. 541-548, 2014.

[85] P. Xiang, L. C. Zhang, X. W. Xu et al., "Geological characteristics and genesis of Yuleken-Halasu superimposed and tectonically reworked porphyry copper-gold (molybdenum) deposit in Qinghe, Xinjiang," Acta Petrologica Sinica, vol. 28, pp. 2369-2380, 2012.

[86] C. J. Xue, Z. F. Zhao, G. G. Wu et al., “The multiperiodic superimposed porphyry copper mineralization in central Asian tectonic region: a case study of geology, geochemistry and chronology of Halasu copper deposit, southeastern Altai, China," Earth Science Frontiers, vol. 17, pp. 53-82, 2010.

[87] X. Qu, X. W. Xu, G. L. Liang et al., "Geological and geochemical characteristics of the Mengxi $\mathrm{Cu}-\mathrm{Mo}$ deposit and its constraint to tectonic setting of the Qiongheba magmatic arc in eastern Junggar, Xinjiang," Acta Petrologica Sinica, vol. 25, pp. 765-776, 2009.

[88] Z. Y. Jia, Study on the magmatic processes and Cu-Mo mineralization in the Lailigaoer-Kengdenggaoer region, western Tianshan, Xinjiang, China, (master thesis), China University of Geosciences, Beijing, 2011.

[89] H. X. Song, Y. L. Liu, W. J. Qu, B. Song, R. Zhang, and Y. Cheng, "Geological characters of Baogutu porphyry copper deposit in Xinjiang, NW China," Acta Petrologica Sinica, vol. 23, pp. 1981-1988, 2007.

[90] M. T. Zhu, G. Wu, H. J. Xie et al., "Re-Os isotopic geochronology and fluid inclusion study of the Lailisigao'er porphyry $\mathrm{Cu}-$ Mo deposit in western Tianshan, Xinjiang, NW China," Acta Petrologica Sinica, vol. 26, pp. 3667-3682, 2010.

[91] Z. H. Zhang, J. W. Mao, Z. L. Wang, A. D. Du, and G. C. Zuo, "Geology and metallogenetic epoch of the Dabate porphyry copper deposit in west Tianshan Mountains, Xinjiang," Geological Review, vol. 52, pp. 683-689, 2006.

[92] Y. Li, Geological and geochemical characteristics and genesis of Dabate Cu-Mo deposit, western Tianshan, Xinjiang, [Ph.D. thesis], China University of Geosciences, Beijing, 2012.

[93] H. Q. Li, D. H. Wang, Y. Wan et al., "Isotopic geochronology study and its significance of the Lailisigaoer Mo deposit, Xinjiang," Acta Petrologica Sinica, vol. 22, pp. 437-2443, 2006.

[94] Q. J. Tu, L. H. Dong, and K. Z. Wang, "Molybdenite Re-Os dating and its geological implication for the east Gebi molybdenum deposit of the eastern Tianshan mountain in Xinjiang," Xinjiang Geology, vol. 30, no. 3, pp. 272-276, 2012.

[95] C. Q. Zhang, D. B. Lou, K. Y. Xiao et al., "Geological characteristics and molybdenite Re-Os isotopic dating of Kumutage Mo deposit, in Hami area, Xinjiang, China," Geological Bulletin of China, vol. 29, pp. 1586-1593, 2010.

[96] X. H. Deng, Y. J. Chen, M. Santosh et al., "U-Pb zircon, Re-Os molybdenite geochronology and Rb-Sr geochemistry from the Xiaobaishitou W (-Mo) deposit: implications for Triassic tectonic setting in eastern Tianshan, NW China," Ore Geology Reviews, vol. 80, pp. 332-351, 2017. 